\title{
Temporal responses of coastal hypoxia to nutrient loading and physical controls
}

\author{
W. M. Kemp ${ }^{1}$, J. M. Testa ${ }^{1}$, D. J. Conley ${ }^{2}$, D. Gilbert ${ }^{3}$, and J. D. Hagy ${ }^{4}$ \\ ${ }^{1}$ University of Maryland, Center for Environmental Science, Horn Point Laboratory, Cambridge, Maryland, USA \\ ${ }^{2}$ GeoBiosphere Science Centre, Department of Geology, Lund University, Lund, Sweden \\ ${ }^{3}$ Maurice-Lamontagne Institute, Department of Fisheries and Oceans, Mont-Joli, Québec G5H 3Z4, Canada \\ ${ }^{4}$ US Environmental Protection Agency, National Health and Environmental Effects Laboratory, Gulf Ecology Division, \\ Gulf Breeze, Florida, USA
}

Received: 26 June 2009 - Published in Biogeosciences Discuss.: 14 July 2009

Revised: 25 November 2009 - Accepted: 6 December 2009 - Published: 15 December 2009

\begin{abstract}
The incidence and intensity of hypoxic waters in coastal aquatic ecosystems has been expanding in recent decades coincident with eutrophication of the coastal zone. Worldwide, there is strong interest in reducing the size and duration of hypoxia in coastal waters, because hypoxia causes negative effects for many organisms and ecosystem processes. Although strategies to reduce hypoxia by decreasing nutrient loading are predicated on the assumption that this action would reverse eutrophication, recent analyses of historical data from European and North American coastal systems suggest little evidence for simple linear response trajectories. We review published parallel time-series data on hypoxia and loading rates for inorganic nutrients and labile organic matter to analyze trajectories of oxygen $\left(\mathrm{O}_{2}\right)$ response to nutrient loading. We also assess existing knowledge of physical and ecological factors regulating $\mathrm{O}_{2}$ in coastal marine waters to facilitate analysis of hypoxia responses to reductions in nutrient (and/or organic matter) inputs. Of the 24 systems identified where concurrent time series of loading and $\mathrm{O}_{2}$ were available, half displayed relatively clear and direct recoveries following remediation. We explored in detail 5 well-studied systems that have exhibited complex, non-linear responses to variations in loading, including apparent "regime shifts". A summary of these analyses suggests that $\mathrm{O}_{2}$ conditions improved rapidly and linearly in systems where remediation focused on organic inputs from sewage treatment plants, which were the primary drivers of hypoxia. In larger more open systems where diffuse nutrient loads are more important in fueling $\mathrm{O}_{2}$ depletion and where
\end{abstract}

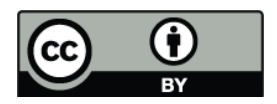

Correspondence to: W. M. Kemp (kemp@umces.edu) climatic influences are pronounced, responses to remediation tended to follow non-linear trends that may include hysteresis and time-lags. Improved understanding of hypoxia remediation requires that future studies use comparative approaches and consider multiple regulating factors. These analyses should consider: (1) the dominant temporal scales of the hypoxia, (2) the relative contributions of inorganic and organic nutrients, (3) the influence of shifts in climatic and oceanographic processes, and (4) the roles of feedback interactions whereby $\mathrm{O}_{2}$-sensitive biogeochemistry, trophic interactions, and habitat conditions influence the nutrient and algal dynamics that regulate $\mathrm{O}_{2}$ levels.

\section{Introduction}

Depletion of dissolved oxygen from coastal waters is a widespread phenomenon that appears to be growing globally (Díaz and Rosenberg, 2008; Gilbert et al., 2009; Rabalais and Gilbert, 2009). There is considerable interest in this phenomenon because low oxygen causes physiological stress for most marine metazoans. Oxygen concentrations below approximately $30 \%$ saturation ("hypoxia" $=\mathrm{O}_{2}<62.5 \mu \mathrm{M}$ or $2 \mathrm{mg}^{-1}$ ) interrupt normal metabolism and behavior of fish and invertebrates causing reduced growth and increased mortality (e.g., Díaz, 2001). Extended periods of hypoxia and relatively brief exposure to anoxia (zero $\mathrm{O}_{2}$ ) tend to cause mortality for many marine animals (e.g., Vaquer-Sunyer and Duarte, 2008). Hypoxia may also affect predator-prey interactions and food web structures, with low $\mathrm{O}_{2}$ zones providing more tolerant organisms extended habitat for foraging and refuge from predation (e.g., Nestlerode and Díaz, 1998; Decker et al., 2004). In addition, low $\mathrm{O}_{2}$ levels

Published by Copernicus Publications on behalf of the European Geosciences Union. 
alter the oxidation-reduction balance in marine sediments and associated biogeochemical processes, including coupled nitrification-denitrification (e.g., Kemp et al., 1990) and inorganic phosphorus sorption to metal oxide-hydroxide complexes (Slomp and van Cappellen, 2007; Middelburg and Levin, 2009).

Oxygen depletion occurs at various time and space scales from an imbalance between biological and physical sources and sinks for $\mathrm{O}_{2}$. In very shallow $(1-5 \mathrm{~m})$ tidal rivers and lagoons with well-mixed water columns that are enriched with inorganic nutrients, hypoxic conditions tend to appear and disappear on short (hours-days) time-scales (D'Avanzo and Kremer, 1994; Tyler et al., 2009). Slightly deeper (3$8 \mathrm{~m}$ ) microtidal systems typically experience periodic stratification that may allow episodic hypoxia to occur on dailyto-weekly scales with changes in wind-driven mixing (Park et al., 2007). In deeper (10-50 m) estuaries and shelf systems with stratified water columns, hypoxia often occurs during much of the summer (2-4 mo) season (e.g., Kemp et al., 1992; Rabalais and Gilbert, 2008). In much deeper (>100 m) coastal seas and fjords, strongly stratified water columns result in virtually permanent hypoxia/anoxia, changing in size and position with decadal-scale variations in circulation (e.g., Zillén et al., 2008).

There is mounting evidence that eutrophication (i.e., anthropogenic nutrient and organic enrichment of waters) is contributing to the expansion of occurrence, intensity, and duration of hypoxic conditions in coastal waters worldwide (e.g., Díaz and Rosenberg, 2008; Gilbert et al., 2009; Rabalais and Gilbert, 2009). Nutrient additions tend to fertilize growth, sinking and decomposition of phytoplankton in bottom waters of estuaries, bays, and inland seas. For many coastal systems in the industrialized regions of the world, there have been major socio-economic commitments to remediate hypoxic zones by reducing nutrient loading from the adjacent catchment and overlying atmosphere (Boesch, 2002; Carstensen et al., 2006). Although reductions in anthropogenic nutrient inputs to coastal systems is the primary means that has been employed to remediate hypoxia associated with eutrophication, biomanipulation approaches have also been suggested, including re-establishment of diminished populations of benthic filter-feeding bivalves that consume phytoplankton directly (e.g., Cerco and Noel, 2007; Petersen et al., 2008). Engineering solutions (including enhanced vertical mixing, increased horizontal exchange, and mechanical air-bubbling) have also been discussed as options for mitigating human-induced coastal hypoxia (Stigebrandt and Gustafsson, 2007; Conley et al., 2009c). Although substantial socio-economic investments have been made to reduce hypoxia in many regions worldwide (e.g., Kronvang et al., 2005), recent analyses of historical data from European and North American coastal systems suggest little evidence for simple and straightforward responses of hypoxia to remediation actions (Duarte et al., 2009; Conley et al., 2009b).
The purpose of this paper is to review published concurrent time-series data (or proxies) on hypoxia and inputs of nutrients and labile organic matter to analyze trajectories of $\mathrm{O}_{2}$ response to reductions in nutrient loading. Where available, we also review parallel time-series data on key physical and ecological processes that might also affect changes $\mathrm{O}_{2}$ conditions in coastal marine waters. To minimize questions about data quality, we limited this review to information published in peer-reviewed literature. While most of the data series in case-studies reviewed here include extended periods ( $>10 \mathrm{yr}$ ) of declining nutrient inputs, a few were characterized more by strong interannual variations rather than longterm trends. The review is structured into seven sections: (1) introduction, (2) external drivers (3) internal processes (4) theoretical response trajectories, (5) hypoxia recovery, (6) complex responses, and (7) concluding comments. Sections 2 and 3 provide background information needed to interpret observed responses in terms of physical, biogeochemical and ecological controls. In Section 4 we describe theoretical trajectories along which hypoxia might be expected to respond to changes in nutrient loading. In the next two sections, we describe case studies of systems showing relatively clear responses to decreased nutrient loading (Sect. 5), and others where hypoxia has exhibited complex responses to fluctuations and changes in nutrient loading (Sect. 6). Section 7 provides conclusions and considers implications for remediating and managing low $\mathrm{O}_{2}$ coastal waters.

\section{External drivers}

Although recent decades have seen widespread observations of hypoxia in diverse coastal systems (e.g., Díaz and Rosenberg, 2008), low $\mathrm{O}_{2}$ conditions in different systems vary across a wide range of temporal (as well as spatial) scales. Here we provide a modified scheme for categorizing hypoxic systems according to scales of variability, and we discuss the major external drivers that regulate $\mathrm{O}_{2}$ conditions by controlling physical transport and mixing as well as ecological production and consumption of organic matter.

\subsection{Topology of coastal hypoxia}

Drawing from previous hypoxia classification schemes based on duration and dominant time-scales of low $\mathrm{O}_{2}$ (e.g., Díaz and Rosenberg, 2008), we define four broad categories of hypoxia: (1) permanent, (2) persistent seasonal, both stratified and vertically mixed, (3) episodic, and (4) diel. Permanent hypoxia occurs primarily in shelf regions, large fjords, and inland seas in which strong stratification isolates the bottom layer of deep water columns $(>100 \mathrm{~m})$, leading to bottom water hypoxia/anoxia (e.g., Helly and Levin, 2004; Gilbert et al., 2005) that tends to change only in size and position with annual-to-decadal scale variations in circulation (e.g., Helly and Levin, 2004; Zillén et al., 2008; Chen et al., 2007). 
Persistent seasonal hypoxia occurs in many stratified temperate estuarine and shelf regions where the combination of spring river discharge and summer heat strengthen stratification, promote phytoplankton growth and stimulate respiration of sinking organic matter (e.g., Rabalais and Gilbert, 2009). Seasonal hypoxia may also occur throughout the water column in shallow well-mixed estuaries and tidal rivers that are heavily loaded with large inputs of labile organic material that are respired in warmer months (e.g., Soertaert et al., 2006). Episodic hypoxia tends to occur at irregular intervals (weeks to decades) in productive, shallow (5-15 m), weakly-stratified microtidal coastal systems that are generally subjected to wind mixing. These systems are susceptible to occasional hypoxic conditions that are terminated by wind events (e.g., Stanley and Nixon, 1992); however, they may be prolonged by extended warm calm weather (Møhlenberg, 1999) or exacerbated by major storm events that deliver large pulses of organic loading (Peierls et al., 2003). Diel hypoxia tends to occur in shallow productive lagoons and bays, when night-time respiration of organic matter produced during the day exceeds $\mathrm{O}_{2}$ replenishment via air-sea exchange. Typically, daytime $\mathrm{O}_{2}$ levels in these shallow systems are high (often supersaturated) because of strong photosynthetic $\mathrm{O}_{2}$ production. Although this paper considers all types of hypoxia, it generally focuses on coastal systems with seasonal hypoxia (persistent or variable) because these systems tend to be well-studied and are often heavily influenced by anthropogenic nutrient enrichment. In contrast, systems with diel hypoxia are less studied, while systems with permanent hypoxia tend to be dominated by natural processes that are difficult or impossible to remediate.

\subsection{Factors driving physical and ecological processes}

In many coastal systems, density stratification is sufficient to create a bottom layer isolated from surface waters and impede downward mixing of $\mathrm{O}_{2}$ from surface waters, thereby reducing physical replenishment and allowing depletion of bottom water $\mathrm{O}_{2}$ through aerobic respiration of accumulated carbon (e.g., Kemp et al., 1992, 2005). Buoyancy of the upper layer is increased and stratification is strengthened by seasonal inputs of fresh water (Boicourt, 1992) and warming of surface waters (e.g., Welsh and Eller, 1991). Relatively weak stratification in systems such as the Neuse River estuary, Long Island Sound, and Mobile Bay can be disrupted by typical summer wind events (e.g., Turner et al., 1987; Stanley and Nixon, 1992; O’Donnell et al., 2008). In any given year, stronger stratification, created by larger freshwater input or warmer surface water, is more resistant to disruption by wind events (Lin et al., 2008). Ventilation of bottomwater hypoxia may involve relatively complex mechanisms, where for example wind stress induces the straining of density fields (e.g., Scully et al., 2005), lateral tilting of the pycnocline (Malone et al., 1986), alteration of far-field coastal circulation (e.g., Wiseman et al., 1997), or interaction with spring-neap tidal cycles (Sharples et al., 1994). In stratified systems with estuarine circulation, bottom-water $\mathrm{O}_{2}$ pools are also replenished by landward transport of $\mathrm{O}_{2}$-rich water from downstream sources or offshore (e.g., Kuo et al., 1991; Kemp et al., 1992; Wiseman et al., 2004). Because hypoxia in stratified coastal systems is confined to the bottom layer, respiration must be fueled by labile organic matter, typically organic particles sinking from the upper water column (e.g., Hagy et al., 2005; Chen et al., 2007, 2009).

Although water-column stratification is a key control on persistent seasonal hypoxia for many systems, other wellmixed coastal waters experience intermittent or persistent hypoxic conditions that are confined to the warm season. For example, vertically mixed shallow brackish tidal rivers and saline lagoons may experience relatively continuous summertime low $\mathrm{O}_{2}$ concentrations if they are receiving heavy loads of labile organic wastes. In industrialized regions of the world prior to 1990 , and even today in densely populated developing countries, large discharges of organic wastes can create high rates of $\mathrm{O}_{2}$ demand that often lead to hypoxic conditions throughout the water column (e.g., Andrews and Rickard, 1980; Soetaert et al., 2006; Díaz and Rosenburg, 2008; Yin et al., 2008). If these systems are relatively turbid due to suspended sediment inputs and resuspension, photosynthesis and associated $\mathrm{O}_{2}$ production would be severely light-limited. In this case, vertical mixing of the water column is typically induced by winds and/or tidal turbulence, and hypoxia results from a sink-source imbalance where community respiration exceeds the rate of $\mathrm{O}_{2}$ replenishment via air-water exchange. In contrast, when shallow, clearwater coastal systems (e.g., lagoons) receive substantial inputs of inorganic nutrients, photosynthetic production (often dominated by benthic plants) represents an important $\mathrm{O}_{2}$ source, leading to diel-scale cycling between supersaturated $\mathrm{O}_{2}$ concentrations during the day and hypoxic conditions at night (e.g., MacPherson et al., 2007; Tyler et al., 2009). Although diel hypoxia is generally confined to the warmer summer months, its occurrence and intensity tends to vary on daily-to-weekly time-scales associated with periodic fluctuations in sunlight and tides, as well as rain and wind events (e.g., Shen et al., 2008). There are surprisingly few reports of diel-scale hypoxia in the scientific literature; however, recent evidence suggests that this phenomenon is widespread in shallow eutrophic waters (e.g., Wenner et al., 2004).

Key ecological controls on seasonal hypoxia in coastal waters involve the production and delivery of labile organic matter to the region of $\mathrm{O}_{2}$ depletion. The origin of the organic matter that fuels respiratory $\mathrm{O}_{2}$ sinks can either be from sources within the aquatic system or from external sources, including the adjacent watershed or ocean (Bianchi, 2007). Major external sources of organic material to coastal waters can be derived from runoff of terrestrial plant debris, phytoplankton biomass from adjacent river-borne or oceanicupwelling sources, and anthropogenic inputs of particulate and dissolved organics, (e.g., sewage effluents; see Sect. 5). 
For non-stratified coastal systems, respiration and hypoxia may be driven by inputs of dissolved organic matter (e.g., Andrews and Rickard, 1980; MacPherson et al., 2007). To fuel bottom respiration in stratified waters, however, organic matter must be in the form of particles capable of sinking to the bottom layer. Most bottom water hypoxia is fueled by sinking of living and detrital phytoplankton cells, whether they are transported from external sources or produced internally in overlying waters. The high rates of particulate organic input generally needed to support bottom-layer hypoxia, however, tend to be from algal production in overlying waters driven by inputs of inorganic nutrients from adjacent sources. Recent reviews of anthropogenic hypoxia suggest that $\mathrm{O}_{2}$ depletion in stratified coastal waters is most often driven by nutrient-stimulated production of organic matter (e.g., Díaz and Rosenburg, 2008).

Long-term trends and decadal-scale cycles in climatic forcing can also exert control over $\mathrm{O}_{2}$ concentrations in bottom waters via changes in temperature, salinity, freshwater inputs, and wind stress (Rabalais et al., 2009). For example, recent increases in water temperature (e.g., Nixon et al., 2004), which are expected to continue with increases in atmospheric $\mathrm{CO}_{2}$ concentrations, will have direct and indirect consequences for hypoxia. The direct effects include decreased solubility of $\mathrm{O}_{2}$ in water and enhanced respiration rates, while indirect effects include changes in food webs resulting from spatial and temporal shifts in species distribution and abundance (e.g., Najjar et al., 2000, 2009; Pyke et al., 2008). In addition, long-term increases in relative sea level occurring in many coastal regions worldwide (Holgate and Woodworth, 2004) may result in elevated bottom water salinities (Hilton et al., 2008), thus potentially enhancing stratification and reducing ventilation of deep waters. Longterm increases or decreases in freshwater input caused by global climate change will influence coastal hypoxia in many coastal systems by increasing or decreasing (respectively) the stratification strength and nutrient delivery rate (e.g., Justić et al., 2003; Arnell, 1999). Lastly, long-term trends and decadal-scale shifts in atmospheric pressure fields and circulation (e.g., Ogi et al., 2003) may alter the magnitude and direction of wind stress, causing changes in vertical mixing and oxygenation of $\mathrm{O}_{2}$-depleted bottom waters in coastal systems (e.g., Wilson et al., 2008, Scully 2009; see Sect. 6).

\section{Internal ecological processes}

Although external forcing of physical and biological processes strongly influences coastal ecosystem dynamics and hypoxia development, internal ecosystem structure and associated processes are also important. For example, internal processes regulate key biogeochemical fluxes, including production and consumption of organic carbon and cycling of inorganic nutrients. These processes, which create positive and negative feedbacks within the ecological system, can in- fluence $\mathrm{O}_{2}$ dynamics in coastal water columns (e.g., Kemp et al., 2005). In this section we review key internal biogeochemical and ecological processes that interact with and regulate hypoxic conditions. This background information is essential for interpreting and predicting how zones of coastal hypoxia will respond to changes in external nutrient loading.

Oxygen depletion in most stratified coastal systems is ultimately supported by surface layer phytoplankton production and particulate sinking to the bottom layer. Herbivorous grazing in the upper water column tends to impede sinking of algal cells and detritus to the lower layer. However, most marine zooplankton are relatively less effective grazers compared to large-bodied cladocerans in lakes, which can strongly control phytoplankton biomass (e.g., Jeppesen et al., 2007). Marine zooplankton (primarily copepods) are less effective because of lower filtering efficiency and strong top-down control by planktivores (e.g., Roman and Gauzens, 1997; Stock and Dunne, 2009). On the other hand, marine suspension-feeding benthic bivalves can effectively control phytoplankton growth, especially in shallow coastal systems (e.g., Prins et al., 1998; Dame and Olenin, 2005), leading to the suggestion that mussels, oysters and other reefforming benthic bivalves could potentially regulate phytoplankton sufficiently to reduce hypoxia in eutrophic coastal systems (e.g., Officer et al., 1982; Newell and Ott, 1999). A requirement for this to be effective is that benthic grazers must have access to upper mixed layer water where they can graze rapidly growing cells and retain organic matter in the shallow aerobic waters (e.g., Pomeroy et al., 2006; Newell et al., 2007). Although field-scale documentation of benthic grazing impacts mitigating coastal hypoxia is limited, several modeling studies have demonstrated potential effectiveness (e.g., Cerco and Noel, 2007; Banas et al., 2007). The observation that substantial reduction in nutrient loading to coastal waters can lead to food-limited conditions for benthic bivalves (e.g., Dame and Prins, 1998) suggests that benthic bivalve consumption of excess phytoplankton production might help retard development and maintenance of hypoxia. Variations in climatic conditions (e.g., increased temperature and rainfall, can initiate low $\mathrm{O}_{2}$ events that weaken benthic filter-feeders, thereby reducing control on phytoplankton and further intensifying hypoxia (e.g., Fallesen et al., 2000; Petersen et al., 2008). Benthic bivalves thus represent potential negative feedback control on phytoplankton whereby hypoxia tends to increase with declines in bivalve populations (see Sect. 6, Chesapeake Bay).

Bottom water $\mathrm{O}_{2}$ concentrations can influence the balance between decomposition and preservation of organic matter deposited on the seafloor through a variety of complex interactions (e.g., Middelburg and Levin, 2009). The fraction of sinking organic matter that is incorporated into the sediments tends to increase with deposition rate, possibly because high rates of organic input fuel $\mathrm{O}_{2}$ depletion, which retards decomposition. This makes it challenging to resolve the relative importance of hypoxia, per se, as a control on 
Table 1. Characteristic categories of coastal hypoxia defined by time-scales of variability and partially controlled by water column depth. See Zhang et al. (2009) for a broader classification.

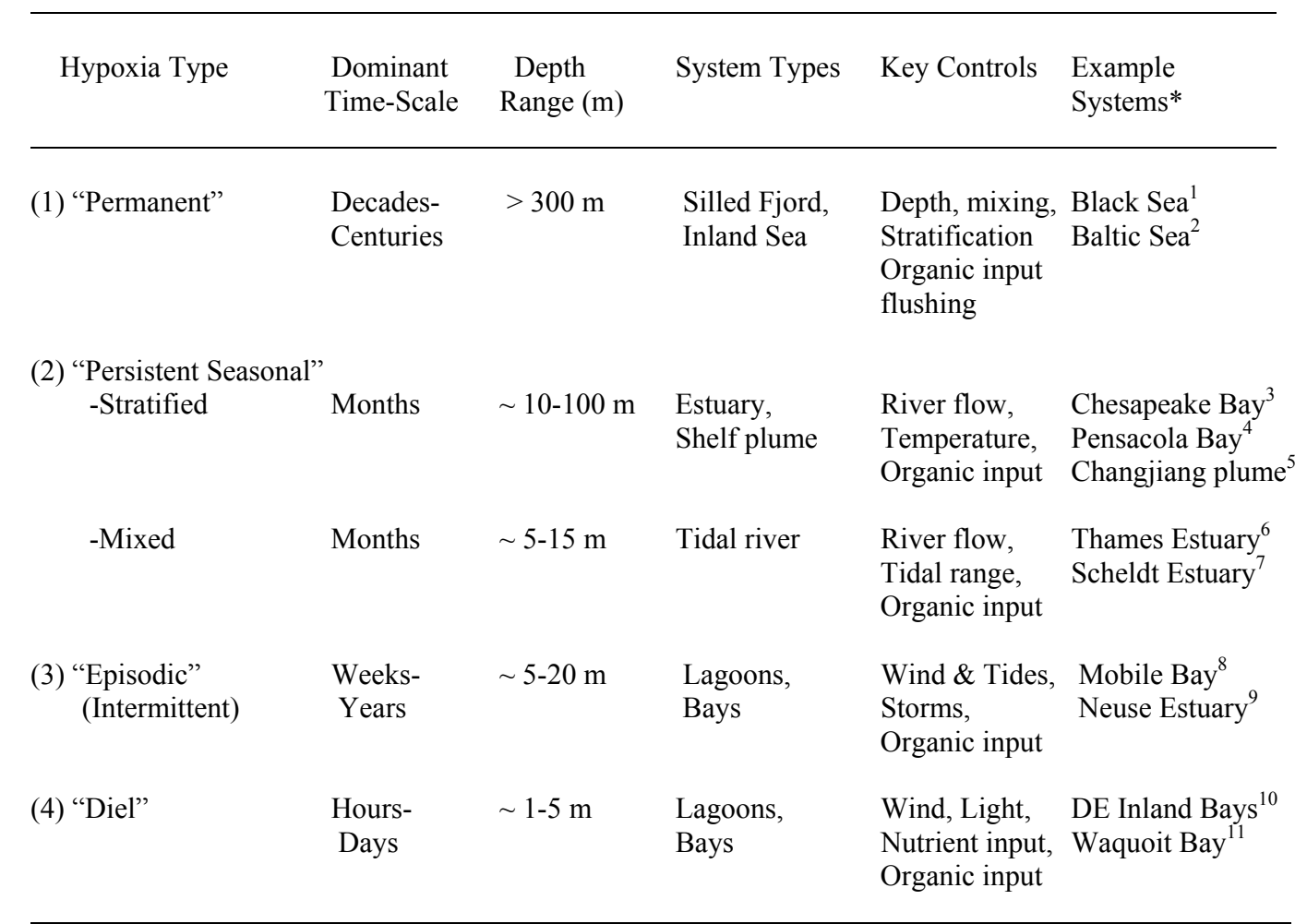

*References: ${ }^{1}$ Mee (2006), ${ }^{2}$ Conley et al. (2007), ${ }^{3}$ Kemp et al. (1992), ${ }^{4}$ Hagy and Murrell (2007), ${ }^{5}$ Chen et al. (2007), ${ }^{6}$ Andrews and Rickard (1980), ${ }^{7}$ Soertaert et al. (2006), ${ }^{8}$ Turner et al. (1987), ${ }^{9}$ Borsuk et al. (2001), ${ }^{10}$ Tyler et al. (2009), ${ }^{11}$ D'Avanzo and Kremer (1994).

decomposition versus physical effects of rapid of burial (e.g., Hedges and Keil, 1995). Numerous experiments where natural organic matter is allowed to decompose under controlled conditions with and without $\mathrm{O}_{2}$ have been generally inconclusive (e.g., Westrich and Berner, 1984); however, more recent laboratory and field investigations tend to support the idea that decomposition rates are retarded by absence of $\mathrm{O}_{2}$ due to a range of mechanisms including loss of macrofauna activity and sulfide inhibition of microbial metabolism (e.g., Middelburg and Levin, 2009). Recent papers (see Sect. 6, northern Gulf of Mexico (NGOM) hypoxia) have speculated that relatively labile organic matter produced in one year could be buried and preserved under seasonally hypoxic conditions, until it is exposed by subsequent physical disturbance in the following year, when decomposition (and $\mathrm{O}_{2}$ demand) would increase under aerobic conditions (e.g., Turner et al., 2008; Bianchi et al., 2008).

Sediment biogeochemical processes, porewater chemistry, and nutrient recycling are clearly influenced by low water column $\mathrm{O}_{2}$ and associated sediment oxidation-reduction (redox) profiles. For both nitrogen $(\mathrm{N})$ and phosphorus $(\mathrm{P})$, benthic recycling efficiency (the fraction of inputs of organic $\mathrm{N}$ and $\mathrm{P}$ to sediments that efflux back to overlying water) tends to increase with decreasing bottom water $\mathrm{O}_{2}$ concentrations (e.g., Kemp et al., 2005). Particulate organic nitrogen delivered to bottom water and the sediment surface is decomposed via hydrolysis reactions using one of several available terminal electron acceptors (e.g., $\mathrm{O}_{2}, \mathrm{NO}_{3}^{-}, \mathrm{Mn}$ (III, IV), Fe (III), and $\left.\mathrm{SO}_{4}^{2-}\right)$, generating inorganic ions of nitrogen $\left(\mathrm{NH}_{4}^{+}\right)$and phosphorus $\left(\mathrm{PO}_{4}^{3-}\right)$ as end-products (Middelburg and Levin, 2009). In the presence of $\mathrm{O}_{2}, \mathrm{NH}_{4}^{+}$tends to be oxidized completely to $\mathrm{NO}_{3}^{-}$(or to $\mathrm{NO}_{2}^{-}$and $\mathrm{N}_{2} \mathrm{O}$ ) by chemoautotrophic nitrifying bacteria, resulting in $\mathrm{O}_{2}$ consumption. Although nitrification may be limited by $\mathrm{NH}_{4}^{+}$availability in sediments with low \% organics, rates in eutrophic coastal systems are more often controlled by depth of $\mathrm{O}_{2}$ penetration into $\mathrm{NH}_{4}^{+}$-rich fine-grain organic sediments (e.g., Henriksen and Kemp, 1988). A substantial fraction of the $\mathrm{NO}_{3}^{-}$ generated in nitrification is generally reduced in surrounding anaerobic zones via denitrification to gaseous $\mathrm{N}_{2}\left(\right.$ or $\left.\mathrm{N}_{2} \mathrm{O}\right)-$ forms that are virtually unavailable for assimilation by plants (e.g., Seitzinger, 1988).

Under conditions with hypoxic overlying water, sediments with low redox levels and high sulfide concentrations favor 
dissimilatory reduction of $\mathrm{NO}_{3}^{-}$back to $\mathrm{NH}_{4}^{+}$over denitrification (e.g., Tiedje, 1987) and strongly inhibit nitrification (e.g., Joye and Hollibaugh, 1995). Although anammox (anaerobic oxidation of $\mathrm{NH}_{4}^{+}$to $\mathrm{N}_{2}$ with $\mathrm{NO}_{2}^{-}$) may occur with anoxia, it is limited by availability of $\mathrm{NO}_{2}^{-}$, and rates tend to be substantially lower than denitrification in most coastal sediments (Revsbech et al., 2006). Thus, hypoxic and anoxic bottom waters greatly suppress nitrification and coupled nitrification-denitrification rates, causing a higher $\%$ of total nitrogen to be recycled to overlying water as $\mathrm{NH}_{4}^{+}$(e.g., Kemp et al., 1990; see Sect. 6). Similar dynamics involving hypoxia and $\mathrm{PO}_{4}^{3-}$ recycling are attributable to totally different mechanisms. Under normoxic conditions, dissolved $\mathrm{PO}_{4}^{3-}$ binds to oxides and hydroxides of $\mathrm{Fe}$ and $\mathrm{Mn}$, forming amorphous solid-phase substances that are retained in sediments (Froelich, 1988). In contrast, hypoxic conditions promote reduction of $\mathrm{Fe}$ and $\mathrm{Mn}$ to soluble states, thereby releasing bound $\mathrm{PO}_{4}^{3-}$ (Froelich et al., 1982). The presence of free sulfide, which has a very high affinity for binding sites on $\mathrm{Fe}$ and $\mathrm{Mn}$, further promotes rapid release $\mathrm{PO}_{4}^{3-}$ and efflux to overlying waters (e.g., Caraco et al., 1989).

Many benthic invertebrate macrofauna (e.g., polychaetes, bivalves, amphipods) are highly susceptible to physiological stresses or mortality from bottom-water hypoxia and anoxia (e.g., Díaz and Rosenberg, 1995; Levin, 2003). Healthy benthic faunal communities can, however, exert strong influence on $\mathrm{N}$ and $\mathrm{P}$ cycling in coastal marine sediments (e.g., Aller, 1982). Although direct excretion by these organisms tends to increase nutrient recycling, activities of many species also retard recycling of $\mathrm{NH}_{4}^{+}$and $\mathrm{PO}_{4}^{3-}$ by enhanced $\mathrm{O}_{2}$ advection into sediment porewaters. Macrofauna burrows, tunnels and tubes that penetrate $(0.2-10 \mathrm{~cm})$ into sediments are ventilated by natural circulation and by active animal pumping of overlying water (e.g., Aller, 1982). Macrofaunal ventilation tends to stimulate sediment nitrification and strengthen its coupling to denitrification by increasing the effective area of oxic-anoxic interfaces (e.g., Pelegri and Blackburn, 1995). Enhanced $\mathrm{O}_{2}$ penetration into coastal sediments also retards dissolution of Fe-Mn-oxide-hydroxide complexes, promoting burial of $\mathrm{PO}_{4}^{3-}$ rather than release to overlying waters (e.g., Welsh, 2003; Middelburg and Levin, 2009). Feeding activities of other benthic fauna can dramatically alter sediment biogeochemistry by homogenizing or vertically transporting particles within the upper $(0-30 \mathrm{~cm})$ sediment column (e.g., Francois et al., 2001). Field observations and modeling studies suggest that vertical mixing of P-bound particles can reduce $\mathrm{PO}_{4}^{3-}$ release from sediments to overlying water in summer (e.g., DiToro, 2001). In summary, hypoxia and anoxia can further stimulate $\mathrm{NH}_{4}^{+}$and $\mathrm{PO}_{4}^{3-}$ recycling to overlying waters by reducing benthic macrofauna bioturbation.

Meadows of tidal marsh and seagrass plants effectively mitigate eutrophication and hypoxia along the coastal margins through dissolved nutrient uptake and particulate nutri- ent trapping (e.g., Kemp et al., 2005). Plant biomass accumulation in marshes and seagrass beds can store $10^{3}$ more dry weight (dw) than phytoplankton, with plant stands sometimes exceeding $1000 \mathrm{~g} \mathrm{dw} \mathrm{m}^{-2}$ (e.g., Valiela, 1995). Integrated nutrient pools contained in these macrophytes plant tissues and associated sediments can dominate coastal biotic nutrient budgets (e.g., Bricker and Stevenson, 1996; Kemp et al., 2005). These plants can respond to $\mathrm{N}$ and $\mathrm{P}$ enrichment by incorporating higher nutrient concentrations into their leaves (e.g., Duarte, 1990). In addition, denitrification rates in marsh and seagrass sediments are often much higher than those in nearby unvegetated sediments, because of enhanced nitrification associated with $\mathrm{O}_{2}$ transported by roots into sediments and interception of nitrate-rich groundwater flux from watersheds (Bricker and Stevenson, 1996). The largest impact that these plants have on coastal $\mathrm{N}$ and $\mathrm{P}$ budgets is derived from their intense trapping of suspended nutrient-rich particles (e.g., Kemp et al., 2005; Boynton et al., 2008). As with benthic macrofauna, however, marsh and especially seagrass plants are also highly vulnerable to negative effects of coastal eutrophication, including reduced water clarity (e.g., Orth et al., 2006) and undermining of belowground tissue (Darby and Turner, 2008).

\section{Theoretical response trajectories}

To our knowledge, there are very few mechanistic models that have effectively predicted responses of eutrophicationinduced coastal hypoxia to remediation, particularly reductions in nutrient loading. Numerical models, which are often used to provide quantitative guidance to the mitigation process, generally predict simple linear reductions in hypoxia in response to reduced nutrient loading (Arhonditsis and Brett, 2004) though recent data suggest that coastal ecosystem responses to nutrient reduction are often more complex (Duarte et al., 2009). Although relatively simple models have been used to hind-cast responses of shallow lakes to such remediation efforts (e.g., Scheffer and Jeppesen, 2007), few numerical forecasts have been documented for coastal systems (Soetaert and Middelburg, 2009). Detailed retrospective observations showing how hypoxia has changed with eutrophication abatement is limited to a few coastal systems (e.g., Díaz and Rosenburg, 2008).

A broad range of possible aquatic ecosystem responses to changes in nutrient loading (Fig. 1) have been defined from theory and observation (e.g., Scheffer et al., 2001; Zhang et al., 2009). In the simplest case, responses of hypoxia and other eutrophication effects might be relatively smooth, continuous and linear, where effects increase and decrease along the same pathway in lock-step with changes in nutrient inputs (Fig. 1a). Alternatively, hypoxia might exhibit little response to an initial increase or decrease in nutrients until the system approaches a "threshold" where relatively small changes in nutrient input cause an abrupt system change 


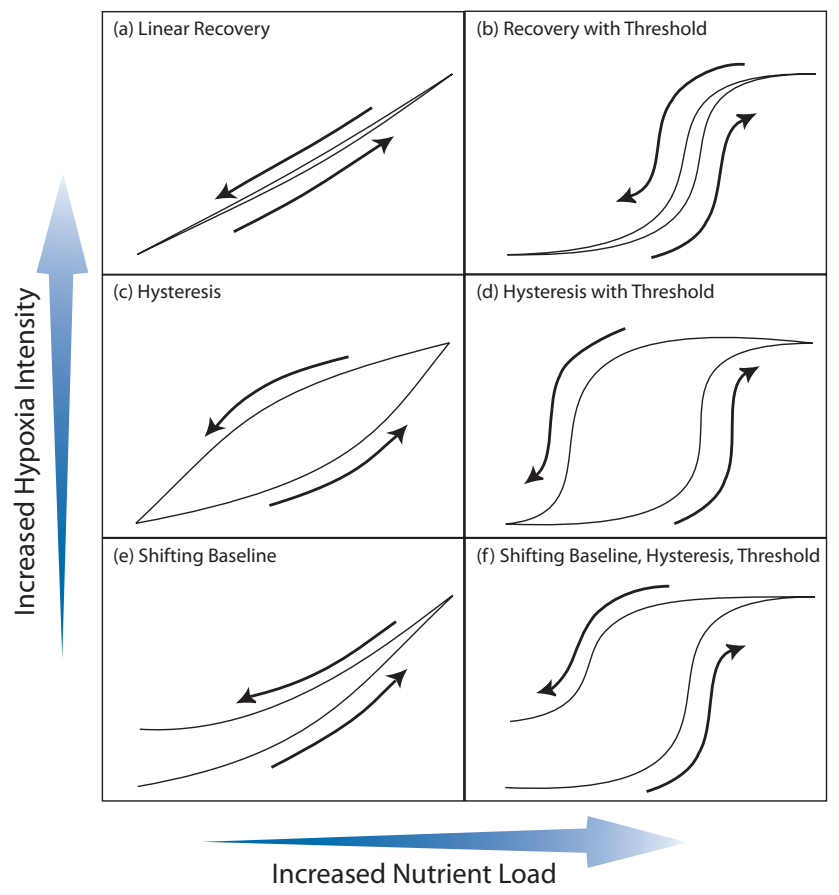

Fig. 1. Six hypothetical response trajectories of oxygen conditions in relation to changes in nutrient load. Trajectories include: (a) linear relationship of hypoxia to load with immediate responses, (b) direct threshold response to nutrient load, (c) delayed (hysteretic) response to nutrient load, (d) threshold response with hysteresis, (e) linear response with shifted baseline due to changes in other forcing variables, and (f) threshold response with hysteresis with a shifted baseline.

(Fig. 1b). In this case, hypoxia again follows the same basic pathway in response to nutrient increase (eutrophication) and nutrient decrease (oligotrophication). If, however, nutrient increases change the fundamental ecosystem character including trophic structure, habitat conditions, and biogeochemical cycles - the system may follow a distinctly different trajectory and reach different endpoints in response to nutrient input declines (Fig. 1c, d, f). These altered ecosystems become resistant to a change in state, and relatively larger nutrient reductions and longer recovery times are required to induce a complete reversal of eutrophication-induced hypoxia and a return to the original state (Fig. 1, Lanthrop and Carpenter, 2008). Many coastal ecosystems are also experiencing disturbance from other factors (e.g., climate change, fishing harvest, species invasion) that can alter hypoxia responses to loading. Thus, these other factors may have caused the "baseline conditions" to change during long intervals between periods of nutrient increase and decrease. Such baseline shifts can lead to situations where complete recovery to pre-eutrophication conditions cannot be readily achieved simply with reduced nutrient loading (Fig. 1e, f), because of other important environmental changes (e.g., Duarte et al., 2009).

\section{Hypoxia remediation with nutrient reduction}

Perhaps the most important assumption of the hypothetical response trajectories presented above is that nutrient loading is the primary driver of hypoxia. Whereas several published cases report time series data documenting contemporaneous increases or interannual variations in hypoxia and nutrient loading (e.g., Hagy et al., 2004; Turner et al., 2006b; Kauppila et al., 2005), there are remarkably few examples with time series data that cover periods of both increasing and decreasing nutrient loads. For stratified coastal systems, strong experimental evidence links nutrient loading, phytoplankton productivity, organic particle sinking, and bottom water $\mathrm{O}_{2}$ consumption (e.g., de Vries et al., 1998); however, the relative balance between this ecological pathway and bottom layer ventilation by vertical mixing is seldom well described. In contrast, the role of labile organic inputs to shallow wellmixed coastal systems in regulating hypoxia has been generally well described (Andrews and Rickard, 1980; Soetaert et al., 2006).

We compiled from the published literature a number of parallel time series of both hypoxia indices and nutrient (and organic matter) loading (or proxies) for several coastal systems to test theoretical expectations of system response to remediation. Available case studies include systems with hypoxia of varying duration (seasonal, episodic, diel), with different anthropogenic inputs fueling hypoxia (inorganic nitrogen or phosphorus, and labile organic matter), and in different system types (well-mixed tidal rivers and shallow lagoons, as well as stratified estuaries, inland seas, and continental shelves). Comparisons of observed responses with hypothetical trajectories described above are made where possible. In general, this analysis suggests that $\mathrm{O}_{2}$ conditions improved rapidly and linearly in systems with large reductions in discharges of labile organic matter from point sources that had been sustaining $\mathrm{O}_{2}$ consumption and hypoxia (Table 2). In larger stratified systems where diffuse input of inorganic nutrients was the primary driver of hypoxia through growth, sinking and decomposition of algal cells, the response to remediation tended to exhibit more complex non-linear behaviors (Table 2).

Improved and more widely applied secondary sewage treatment in the 1960s, 1970s, and 1980s led to major reductions in loads of dissolved and particulate labile organic material (or biochemical oxygen demand, BOD) to coastal waters (e.g., Smith et al., 1987). One striking example is the inner Thames estuary, which received high loads of nutrients and organic matter from two major London sewage treatment plants (STP) through the 1960s and 1970s, causing summer dissolved $\mathrm{O}_{2}$ to remain well below saturation levels (e.g., Andrews and Rickard, 1980) for a stretch of river $(>20 \mathrm{~km})$ seaward of London Bridge (Tinsley, 1998). Installation of secondary treatment at the major STPs reduced BOD loads by $80 \%$ in the early 1970 s, resulting in a return of non-hypoxic summer $\mathrm{O}_{2}$ levels (Fig. 2), followed by a 
Table 2. Summary of reported changes in dissolved oxygen for coastal ecosystems in the peer-reviewed literature, including the dominant loading source, target pollutant, and suggested trajectory of the response.

\begin{tabular}{|c|c|c|c|c|c|c|}
\hline System & Hypoxia Type & Loading Source & Target $^{1}$ & Response $^{2}$ & $\begin{array}{l}\text { Trajectory } \\
\text { Type }\end{array}$ & Reference \\
\hline Baltic Sea proper & Permanently Stratified & Diffuse/ Point & Nut. & No Red. & None & Conley et al., 2009a \\
\hline Boston Harbor & Seasonal Stratified & Point & Nut./BOD & + & Unknown $^{3}$ & Díaz et al., 2008 \\
\hline Charlotte Harbor & Seasonal Stratified & Point & Nutrients & + & Unknown $^{3}$ & Turner et al., 2006a \\
\hline Chesapeake Bay & Seasonal Stratified & Diffuse/ Point & Nut. & - & Reg. Shift ${ }^{4}$ & Hagy et al., 2004 \\
\hline Danish Coastal Waters & Seasonal Stratified & Diffuse/Point & Nut. & None & Reg. Shift ${ }^{4}$ & Conley et al., 2007 \\
\hline N. Gulf of Mexico & Seasonal Stratified & Diffuse & Nut. & No Red. & Reg. Shift ${ }^{4}$ & Turner et al., 2008 \\
\hline Delaware estuary & Seasonal Mixed & Point & Nut./BOD & + & Linear $^{5}$ & Patrick, 1988 \\
\hline East River & Seasonal Mixed & Point & Nut./BOD & + & Linear $^{5}$ & Parker and O'Reily, 1991 \\
\hline Forth estuary & Seasonal Mixed & Point & Nut./BOD & + & Unknown $^{5}$ & Balls et al., 1996 \\
\hline Lajaalahti Bay & Seasonal Mixed & Point & Nut./BOD & + & Linear $^{5}$ & Kauppila et al., 2005 \\
\hline Los Angeles Harbor & Seasonal Mixed & Point & Nut./BOD & + & Unknown $^{3}$ & Reish, 2000 \\
\hline Lower Hudson & Seasonal Stratified & Point & Nut./BOD & + & Linear $^{5}$ & Brosnan and O'Shea, 1996 \\
\hline Lower Patuxent estuary & Seasonal Stratified & Point & Nut. & - & Unknown $^{3}$ & Testa et al., 2008 \\
\hline Mersey estuary & Seasonal Mixed & Point & BOD & + & Unknown $^{3}$ & Jones, 2006 \\
\hline New River estuary & Seasonal Stratified & Point & Nut. & + & Unknown $^{3}$ & Mallin et al., 2006 \\
\hline New York Harbor & Seasonal Stratified & Point & Nut./BOD & + & Linear $^{5}$ & Parker and O'Reily, 1991 \\
\hline Nervión estuary & Seasonal Stratified & Point & Nut./BOD & + & Unknown $^{3}$ & Borja et al., 2006 \\
\hline NW Shelf Black Sea & Seasonal Stratified & Diffuse/ Point & Nut. & + & Hysteresis & Mee, 2006 \\
\hline Raritan Bay & Seasonal Mixed & Point & Nut./BOD & + & Linear $^{5}$ & Parker and O'Reily, 1991 \\
\hline Scheldt estuary & Seasonal Mixed & Diffuse/ Point & Nut./BOD & + & Linear $^{5}$ & Soetaert et al., 2006 \\
\hline Thames estuary & Seasonal Mixed & Point & BOD & + & Threshold & Andrews and Rickard, 1980 \\
\hline Upper Patuxent estuary & Seasonal Stratified & Point & Nut. & + & Linear $^{5}$ & This study \\
\hline Upper Potomac estuary & Seasonal Stratified & Point & Nut & + & Linear $^{5}$ & Kemp et al., 2005 \\
\hline Western LIS & Seasonal Stratified & Point & Nut./BOD & - & Hysteresis & Wilson et al., 2008 \\
\hline
\end{tabular}

${ }^{1}$ Nut. $=$ Nutrients, BOD $=$ biochemical oxygen demand.

$2+=$ improvement, $-=$ degradation, None $=$ no response, No Red. $=$ No reduction in load.

${ }^{3}$ Unknown $=$ data too limited to reveal both degradation and recovery trajectory.

${ }^{4}$ See Conley et al., 2009b for regime shift analysis.

${ }^{5}$ Relationship of $\mathrm{O}_{2}$ and nutrient loading was significantly and linearly related or publication cited a rapid response to remediation.

recovery of fish, benthic macroinvertebrates, and benthic algal communities (Andrews and Rickard, 1980). Although no data were available to describe the time course of degradation (hypoxia development), the remediation response of $\mathrm{O}_{2}$ (\% saturation) versus BOD load suggests threshold behavior, where $\mathrm{O}_{2}$ conditions improved slowly until $\sim 70 \%$ of the load was removed, followed by rapid response to the final $30 \%$ of BOD removal (Fig. 2). The explanation for this threshold is unclear; however, it may reflect that community respiration had been saturated with respect to organic loading, where $\mathrm{O}_{2}$ levels began to increase only after loading decreased sufficiently for respiration to become substrate-limited. Alternatively, a decline in turbidity following waste load reductions may have been sufficient to allow net photosynthesis by benthic algae, which would augment $\mathrm{O}_{2}$ replenishment during summer (Andrews and Rickard, 1980). A final possibility is that BOD loading from other, upstream STPs remained high (and kept $\mathrm{O}_{2}$ low) during the initial phase of 

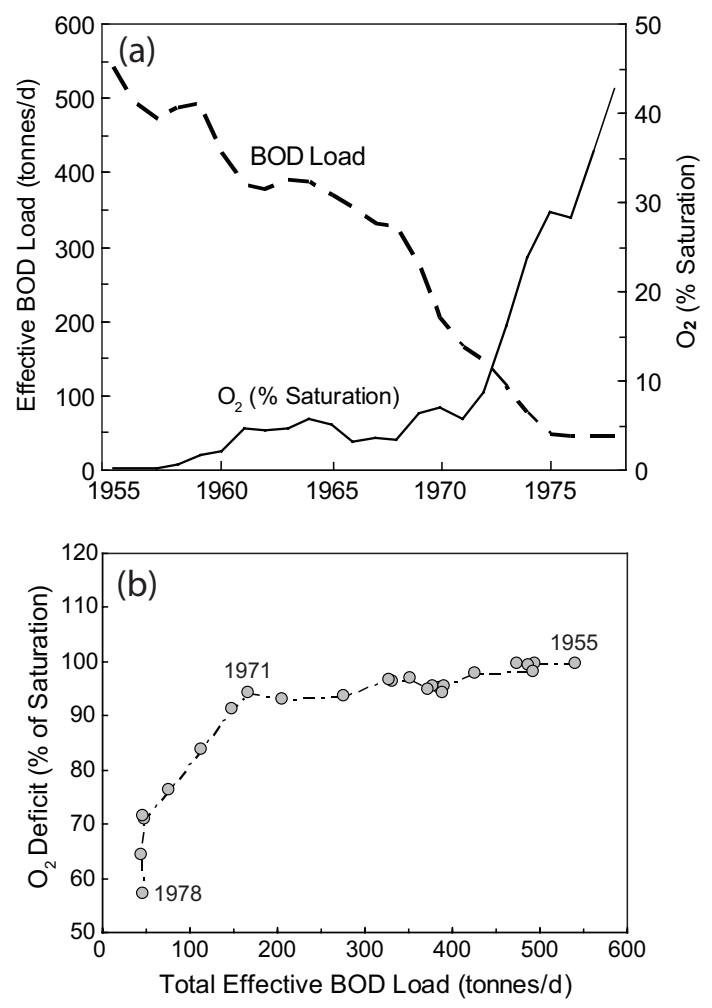

Fig. 2. Time series (1955-1980) of observations in the upper Thames River estuary (England) for (a) BOD load from major sewage treatment plants and summer $\mathrm{O}_{2} \%$ saturation, and (b) relationship of $\mathrm{O}_{2} \%$ saturation deficit (concentration units below mean saturation) to $\mathrm{BOD}$ load showing threshold response of $\mathrm{O}_{2}$ to reduced BOD load. Data are from Andrews and Rickard (1980).

the remediation. Several other recently published time series data from shallow well-mixed estuaries have also documented hypoxia responses to increases and decreases in BOD loading from STPs (Table 2). These case studies, including the Delaware River estuary (Patrick, 1988), the lower Hudson River and adjacent estuaries (Brosnan and O'Shea, 1996; O'Shea and Brosnan, 2000), and the Mersey estuary (Jones, 2006), have generally reported relatively positive and rapid responses to reduced BOD inputs.

The Scheldt estuary is another example of a shallow, turbid, and eutrophic upper estuarine system that responded strongly to changes in both nutrient and organic matter loading (Soetaert et al., 2006). The tidal Scheldt is a macrotidal, relatively shallow $(\sim 10-12 \mathrm{~m})$ estuary that received increasing nutrient and organic loads through the 1970s. Declining $\mathrm{O}_{2}$ levels during this period were linearly related to loading and associated both with oxidation of $\mathrm{NH}_{4}^{+}$(nitrification) and respiration of organic matter (Fig. 3). It appears that nutrient-stimulated algal production was not an important source of organic matter to fuel $\mathrm{O}_{2}$ depletion in this system because of high turbidity and associated light limitation. When improved sewage treatment reduced BOD loads in the
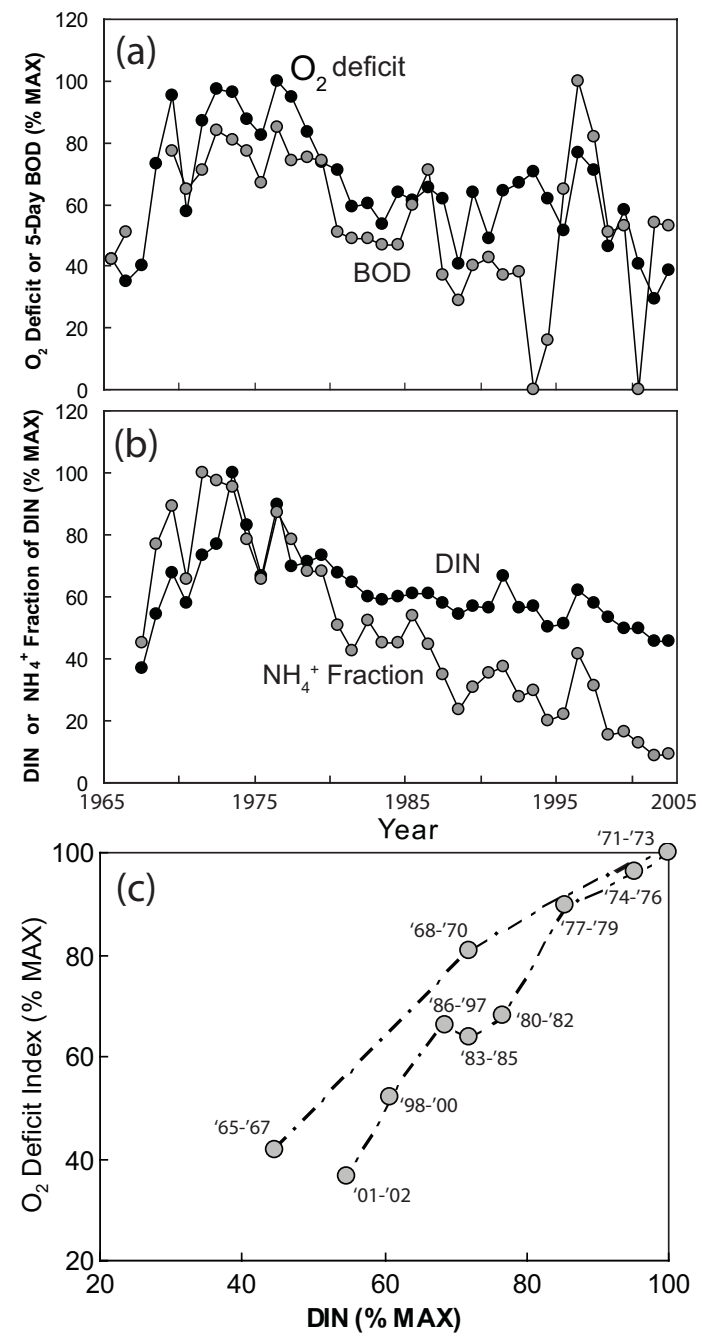

Fig. 3. Time series (1965-2002) of observations at a brackish water station near the Dutch-Belgian border in the Scheldt River estuary (Netherlands) for (a) BOD and $\mathrm{O}_{2} \%$ saturation deficit and for (b) DIN concentrations and fraction of DIN as $\mathrm{NH}_{4}^{+}$and (c) relationship of $\mathrm{O}_{2}$ deficit index to DIN concentration, showing a favorable linear shifting baseline response of $\mathrm{O}_{2}$ to reduced DIN and BOD loads. Data are from Soetaert et al. (2006).

mid-1970s, $\mathrm{O}_{2}$ returned to pre-load levels (Fig. 3) over a 20year period. We explored relationships between $\mathrm{O}_{2}$ deficits and DIN concentrations (proxy for nutrient loading) in the upper Scheldt to examine the response trajectory of $\mathrm{O}_{2}$ to nutrient loading (Fig. 3). Although data on $\mathrm{N}$ loading were not available (Soetaert et al., 2006), both DIN and phytoplankton chlorophyll- $a$ declined in the upper Scheldt during the period of reported nutrient load reduction. Plots of $\mathrm{O}_{2}$ deficit versus DIN concentration revealed that the slope of $\mathrm{O}_{2}$ increase with DIN reduction was flatter than the slope of $\mathrm{O}_{2}$ decline during increasing DIN (Fig. 3). This trajectory reveals a "favorable" shifted baseline scenario that appears to be related, in part, to a declining ratio of $\mathrm{NH}_{4}^{+}$to $\mathrm{NO}_{3}^{-}$loading and concomitant BOD loading reductions (Fig. 3) during this period 
(Soetaert et al., 2006). A direct but more complex response to nutrient load reduction has also been reported for the tidal fresh region of the Scheldt (Cox et al., 2009). This success of remediation in the Scheldt despite complicating changes in nutrient ratios, biogeochemistry, and climate (Soetaert et al., 2006) underscores the ability to control low $\mathrm{O}_{2}$ conditions in shallow tidal estuaries dominated by point source inputs of nutrients and labile organics.

Laajalahti Bay is a shallow $(\sim 2.4 \mathrm{~m})$, well-mixed, semienclosed estuary adjacent to Helsinki and connected to the Gulf of Finland by a series of straits and sounds (Kauppila et al., 2005). Although the well-mixed nature of the estuary generally prevented anoxia from occurring in this estuary, hypoxic conditions were relatively common during the mid 1960s when nutrient and BOD loads were highest (Fig. 4). Improved sewage treatment in the late 1960s led to a steep decline in nutrient and BOD loading to the estuary, and $\mathrm{O}_{2}$ levels increased linearly following a decline in BOD loading then stabilized in the early 1980s (Fig. 4). Further remediation occurred when STP effluents were diverted to the outer archipelago in the mid-1980s, resulting in a second increase in $\mathrm{O}_{2}$ to near saturation levels (Fig. 4). This second $\mathrm{O}_{2}$ increase was significantly and linearly correlated with a decline in chlorophyll- $a$, which was in turn related to decreased TN loading. Improvements in $\mathrm{O}_{2}$ were, however, likely also affected by removal of the remaining BOD loads following the diversion (Kauppila et al., 2005). Both phases of remediation in Laajalahti Bay caused a linear increase in $\mathrm{O}_{2}$, one via reduced BOD input and a second linked primarily to reduced inputs of inorganic nutrients (but also BOD). These examples suggest that low $\mathrm{O}_{2}$ conditions in shallow and well-mixed coastal systems respond positively and rapidly to reductions in both inorganic nutrients and labile organic matter.

In coastal systems where only nutrient loads were reduced, few examples exist where data show that hypoxia decreased markedly with decreased nutrient loading. Where positive $\mathrm{O}_{2}$ responses have been documented (e.g., Mallin et al., 2005), increases were relatively small despite significant declines in nutrient concentrations. To improve $\mathrm{O}_{2}$ conditions, reductions in nutrient loading must first cause decreases in the phytoplankton biomass and production that fuels $\mathrm{O}_{2}$ consumption. Although non-linear responses of phytoplankton biomass to nutrient loading reduction have been reported for many coastal systems (e.g., Duarte et al., 2009), there is a growing number of examples where reductions in algal biomass have been linearly correlated with decreasing nutrient loading (e.g., Henriksen, 2009; van Beusekom et al., 2009). In many large stratified coastal systems, physical processes (e.g., wind stress, river flow, and tidal mixing) play key roles in $\mathrm{O}_{2}$ depletion, where variations in ventilation of bottom waters may dominate the $\mathrm{O}_{2}$ balance and control hypoxia formation. Thus, climate-induced changes in circulation and mixing at decadal or longer scales might mask hypoxia responses to decreases nutrient loading, even if organic production and ecosystem respiration decline significantly.

\section{Complex responses of hypoxia to nutrients}

Recent studies have revealed complex, dynamic relationships between hypoxia, nutrient loading, food webs, and climate for a number of well-studied coastal systems including Chesapeake Bay and its tributaries (e.g., Hagy et al., 2004; Testa et al., 2008), the northern Gulf of Mexico (Turner et al., 2009), the Black Sea (Oguz and Gilbert, 2007), the Baltic Sea (Conley et al., 2009a), Long Island Sound (Wilson et al., 2008), the Danish Coastal straits (Conley et al., 2007), and the shelf region off the northwestern United States (Chan et al., 2008). In several cases, the complexity of responses was manifested in terms of the extent of hypoxia water generated per unit nitrogen loading. For example, the Patuxent River estuary, Chesapeake Bay, and the northern Gulf of Mexico have all exhibited relatively abrupt increases (by more than 2fold) in hypoxia per N-loading occurring between 1983 and 1993 (Fig. 5). Although these increases may be caused by different factors in different systems, the changing hypoxialoading relationship underscores the importance of interactions among multiple ecological and physical factors in regulating coastal hypoxia. In this section, we review and analyze selected case studies toward improved understanding of hypoxia responses to remediation in large coastal ecosystems.

\subsection{Patuxent River estuary}

The Patuxent River estuary, which is a tributary system of Chesapeake Bay, is characterized by two-layered circulation (seaward-flowing surface layer and landward-flowing bottom layer) during most of the year. The mesohaline region has broad shoals $(<6 \mathrm{~m})$ flanking a deep channel $(>10 \mathrm{~m})$ with bottom waters that experience hypoxia each year in summer (May-September). Large interannual variations in hypoxia volume and duration are driven largely by changes in freshwater flow and associated nutrient loading and stratification (Testa et al., 2008). Although episodic low- $\mathrm{O}_{2}$ bottom water has been reported since 1940s (Newcombe et al., 1939), large persistent bottom water hypoxic zones have been evident for the last 5 decades following increased urbanization in the upper watershed (D'Elia et al., 2003).

In an effort to decrease hypoxia and other eutrophication effects, upgrades to sewage treatment reduced loads of TN (via Biological Nitrogen Removal, or BNR) and TP (via chemical precipitation) from point sources, thereby reducing total $\mathrm{N}$ and $\mathrm{P}$ inputs to the estuary by $25-30 \%$ in the mid 1980s for P and early 1990s for N (Fig. 6). Associated with nutrient loading reductions, there have been significant decreases in DIN and DIP concentrations throughout the estuary, as well as declines in phytoplankton chlorophyll- $a$ (chla) and light-saturated carbon fixation for the upper estuary (Testa et al., 2008). Bottom water $\mathrm{O}_{2}$ in the upper estuary increased rapidly following the nutrient load reductions, where hypoxia now rarely occurs during summer (Fig. 6). Despite the improvements in the upper estuary and reduced transport 

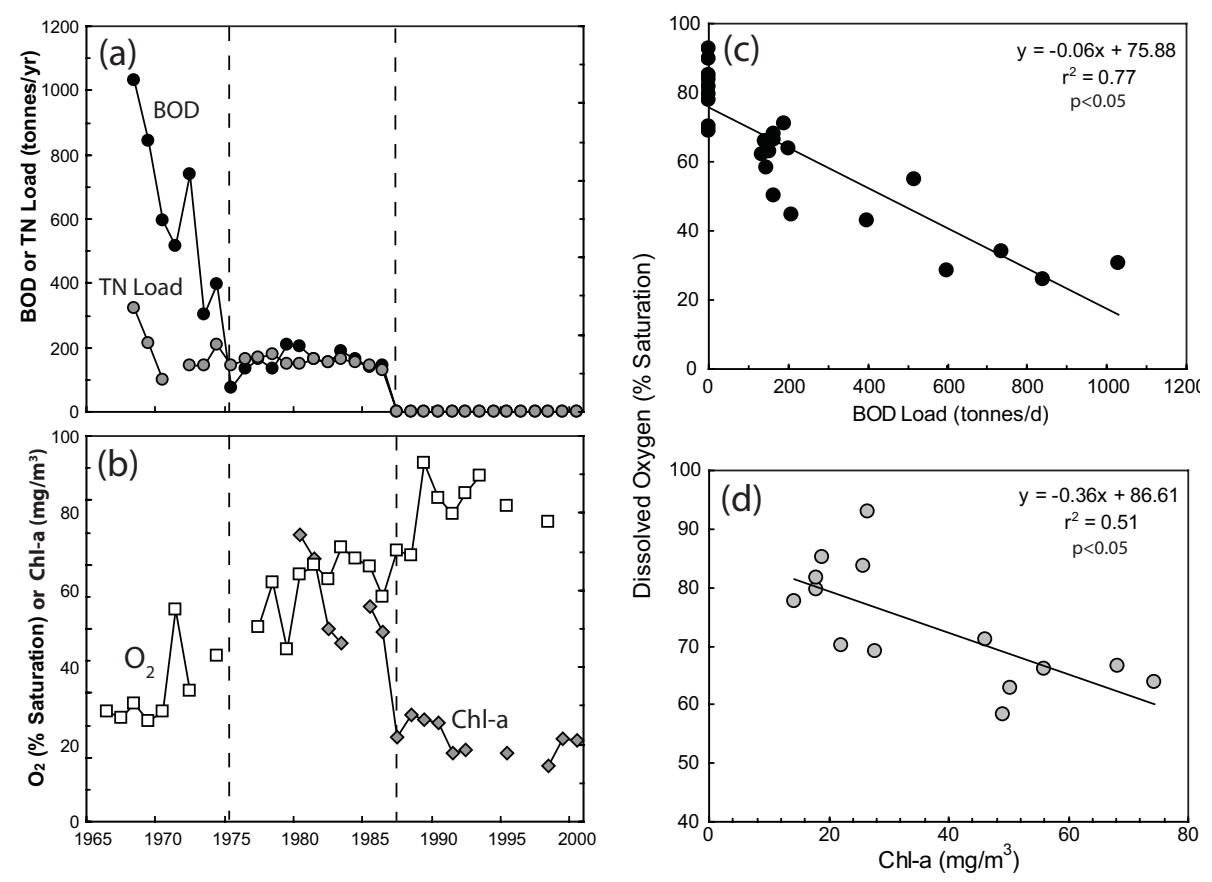

Fig. 4. Time series (1965-2000) observations in Laajalahti Bay (Finland) of (a) BOD and TN loads and of (b) $\mathrm{O}_{2} \%$ saturation and chlorophyll- $a$. Relationship of (c) $\mathrm{O}_{2} \%$ saturation to BOD Load and (d) $\mathrm{O}_{2} \%$ saturation to chlorophyll- $a$. Data are from Kauppila et al. (2005).

of $\mathrm{N}$ and $\mathrm{P}$ to the lower estuary, the total hypoxic volume in the estuary has not changed (Fig. 6).

Analysis of time series data revealed two separate, but positive correlations between $\mathrm{NO}_{3}^{-}$load from the watershed and volume of bottom water hypoxia when data were parsed into pre- and post-BNR years, with more hypoxic volume per unit $\mathrm{NO}_{3}^{-}$load after BNR was initiated (1990; Testa et al., 2008). Elevated hypoxia per unit $\mathrm{N}$ load (Fig. 5) corresponded to increases in summer chl- $a$, turbidity, and surface-layer net $\mathrm{O}_{2}$ production in the lower estuary since 1990 (Fig. 6). This degradation of water quality and persistence of high hypoxic volume in the lower estuary appears to be linked to three unexpected changes in external and internal factors driving hypoxia. First, after 1990 annual input of DIN to the Patuxent estuary via bottom-layer transport from the nutrient-rich Chesapeake Bay began to increase at a mean rate sufficient to offset the reduced loading from upstream (Fig. 6). Secondly, several consecutive years with above-average river flow and associated watershed nutrient loading in the mid1990s contributed to strong stratification and elevated watershed N-loading (Testa et al., 2008). Lastly, an abrupt increase in populations of the planktivorous ctenophore, Mnemiopsis leidyi (Purcell and Decker, 2005) significantly reduced summer abundance (and potential phytoplankton grazing) of the calanoid copepod, Acartia tonsa, from 1990 to 2002 (Fig. 6). Thus, to relieve hypoxia in estuaries like the Patuxent, which are tidally connected to nutrient-rich downstream waters, nutrient inputs must be managed from both landward and seaward sources where possible (Jordan et al., 1991; de Jonge, 1997), while potential effects of trophic interactions must also be considered in evaluating hypoxia responses to remediation.

\subsection{Northwestern shelf of the Black Sea}

The Black Sea, which is the largest enclosed sea in the world, receives freshwater, nutrient, and sediment loads from Europe and Asia via the Danube and other rivers (Lancelot et al., 2002). Centuries of human impact have affected the Black Sea, but large ecosystem changes over the past 50 years dramatically affected nutrient and $\mathrm{O}_{2}$ levels, biogeochemical processes, and trophic relations (Oguz and Gilbert, 2007). A deep and permanently anoxic basin exists in the central part of the Black Sea, but seasonal (summer) hypoxia has occurred on the Sea's northwestern (NW) shelf, which is directly influenced by the Danube River discharge. Although areas of hypoxic bottom-water on the NW shelf have been observed to varying extents since the early 1970 s (Mee, 2006), recent reports indicate that this shelf hypoxic zone has nearly disappeared with dramatic reductions in agriculturally-based nutrient loading in the late 1980s (Mee, 2006; Rabalais et al., 2009).

Hypoxic waters, which were first observed on the northwest shelf in the summer of 1973, occurred annually until 1993, with substantial inter-annual variability (Fig. 7, Mee, 2006). The extent of hypoxia on the northwestern shelf has 

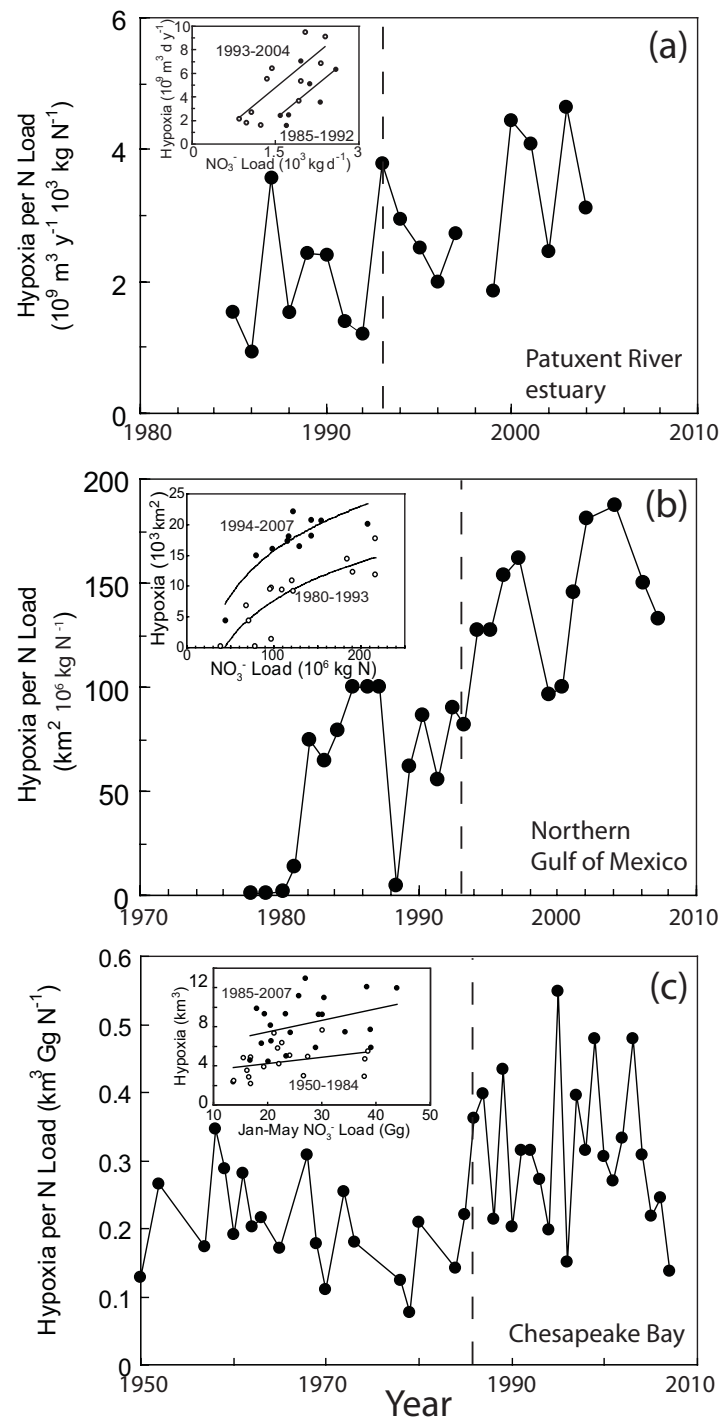

Fig. 5. Multi-decadal time series data for hypoxia per unit nitrogen load in the (a) Patuxent River estuary, USA, (b) northern Gulf of Mexico, USA, and (c) Chesapeake Bay, USA. Inset figures are relationships between $\mathrm{N}$ load and hypoxia for each system during periods before and after statistically significant change points (vertical dashed lines) in time-series of hypoxia per unit $\mathrm{N}$ load. Patuxent data are from Testa et al. (2008), Gulf of Mexico data are from Turner et al. (2008), and Chesapeake data are from Hagy et al. (2004).

been linked to elevated phytoplankton biomass, which increased from the early 1970s to a peak in the 1980s with increased nitrogen and phosphorus fertilizer use and loads from the Danube River (Fig. 7, Mee, 2006). Following the collapse of the former Soviet Union and Warsaw Pact governments in Eastern Europe in the late 1980s, agricultural subsidies were greatly reduced, causing abrupt and substantial declines in fertilizer use and animal agriculture. The resulting large decrease in Danube watershed's N and P fertil- izer use was quickly followed by the virtual disappearance of the associated hypoxic area by 1993 (Fig. 7, Mee, 2006; Oguz and Gilbert, 2007). Parallel time-series of hypoxia and both $\mathrm{N}$ and $\mathrm{P}$ fertilizer application (proxies for nutrient loading) suggest a threshold response of hypoxia to increasing nutrient input, where nutrient loads increased for more than a decade before hypoxia appeared (Fig. 7). While the explanation for this threshold is unclear, Danube River nutrient loading, as well as chl- $a$ in the open Black Sea (Oguz and Gilbert, 2007), have generally followed trends in fertilizer use (Behrendt et al., 2005).

As fertilizer use began to decline in the late 1980s, hypoxic areas were still observed for $\sim 5$ years (1989-1993). This brief hysteretic time-lag may be linked multiple factors: First, a period of sustained phytoplankton production on the northwestern shelf occurred in concert with depressed zooplankton grazing and enhanced upward mixing of nutrientrich deep water into the photic zone in the adjacent, open Black Sea (Oguz and Gilbert, 2007). Secondly, the observed shift in the N:P ratio in the loading may have caused a shift from $\mathrm{N}$ - to P-limitation for phytoplankton growth on the shelf (Fig. 7; T. Oguz, personal communication, 2009). Finally, sustained $\mathrm{N}$ and $\mathrm{P}$ loading may have occurred despite reduced fertilizer application, due to residual nutrient (especially $\mathrm{NO}_{3}^{-}$) pools in groundwater and soils (Behrendt et al., 2005). By the mid-1990s, continued nutrient loading reductions, recovered zooplankton and benthic communities, and reduced wintertime mixing appear to have helped decrease the extent of hypoxia (Mee, 2006; Oguz and Gilbert, 2007). Although physical and ecological factors modulated the effects of nutrient loading on hypoxia in the Black Sea NW shelf, this system represents a relatively rare example of how a major reduction in diffuse nutrient loading can dramatically reduce or eliminate hypoxia.

\subsection{Baltic Sea}

The Baltic Sea is a large and permanently stratified estuary in northern Europe that receives freshwater inflow from an expansive watershed and salt water inflow with North Sea intrusions via the Kattegat, Skagerrak, and Danish straits. Hypoxia has been present in the Baltic Sea to varying degrees since the Holocene, when the previously freshwater lake was connected to the adjacent ocean, and brackish conditions were established (Zillén et al., 2008). Evidence suggests that the extent of hypoxic water in the Baltic has, however, increased since 1950 (Jonsson et al., 1990). Expanding hypoxic areas appear to have accompanied increased nutrient loads derived from the large and populous Baltic watershed, which includes parts of Scandinavia and Eastern Europe (Conley et al., 2009a). Concerted international efforts to reduce eutrophication and hypoxia in the Baltic Sea have been unsuccessful thus far. Below we explore the factors responsible for controlling the extent of hypoxia in this ecosystem. 

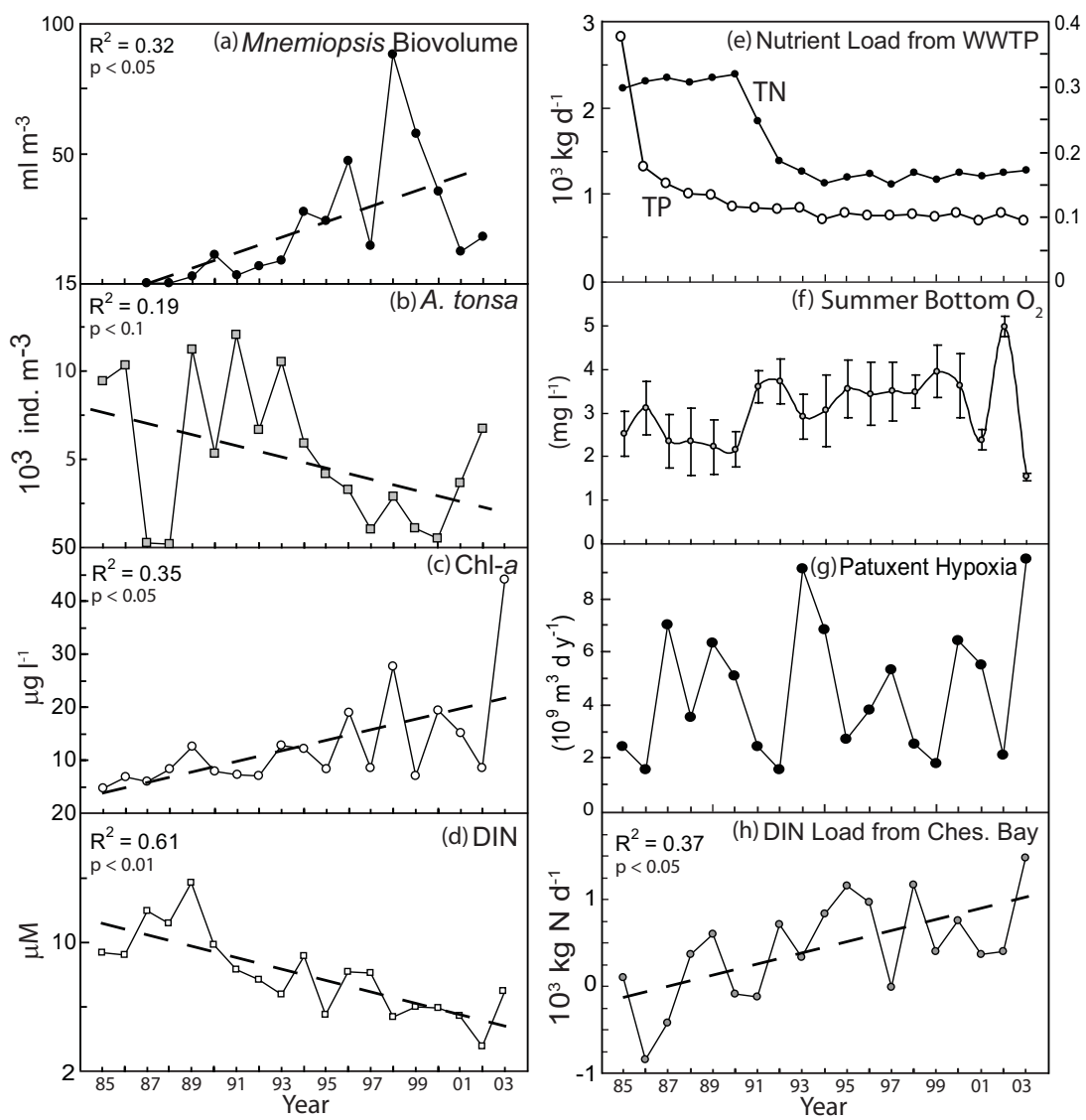

Fig. 6. Time series and trend lines (1985 to 2003) of annual mean June-August concentrations (a) Mnemiopsis sp. biovolume, (b) Acartia tonsa abundance, (c) chlorophyll- $a$, and (d) DIN, and (e) mean annual TN (left axis) and TP (right axis) loads from upstream sewage plants, (f) upper Patuxent summer (June-August) mean concentrations of bottom water $\mathrm{O}_{2}$, (g) hypoxic volume days in the entire Patuxent River estuary, and (h) mean annual DIN inputs from Chesapeake Bay to the Patuxent River estuary. Data are from Testa et al. (2008).

The time-series data describing Baltic Sea hypoxia span from 1960 to the present (Fig. 8, Conley et al., 2009a). A steady decline in the extent of hypoxia from 1970 through 1993 is easily apparent against a small background of interannual variability (Fig. 8). The latter decade of the decline (1985-1995) is associated with a decrease in total phosphorus (TP) load and concentration (Fig. 8), which upon first inspection would suggest that nutrient load remediation efforts were successful. However, a steady increase in hypoxic area and dissolved inorganic phosphorus (DIP) occurred from 1993 to 2000, despite no apparent increase in TP load (Fig. 8). Increased DIP levels appear to be attributable both to sustained external $P$ inputs and to increased internal $P$ loading, where iron-bound $\mathrm{P}$ was presumably released from sediments in larger quantities during the expansion of hypoxic bottom area from the mid-1990s to early 2000s (Conley et al., 2002; see Sect. 3).

Shifts in climate and physical circulation appear also to have been involved in both the decrease in hypoxic area prior to 1993, and the subsequent hypoxia increase (Fig. 8). The Baltic Sea proper is permanently stratified and has fairly lim- ited exchange with adjacent oceanic waters. Thus, mechanisms replenishing $\mathrm{O}_{2}$ to bottom waters via both vertical cross-pycnocline mixing and water renewal via the Danish straits are highly restricted. These processes, which are controlled by physical circulation, may set an upper limit on Baltic hypoxia (Conley et al., 2009a). The 1993 hypoxia minimum followed a 10-year period of low salt water inflows through the Danish straits (Fig. 8). This served to reduce stratification and enhance downward mixing of $\mathrm{O}_{2}$ (Conley et al., 2009a), as inferred by a steady decline in deep water $(200 \mathrm{~m})$ salinity in the Gotland Deep through the 1980s to a minimum in 1992 (Fonselius and Valderrama, 2003). A return of inflowing salt water, documented in the early 1990s, probably continued and caused increasing deep water salinity from 1992-2000 (Fig. 8). This would be expected to increase stratification strength (Fonselius and Valderrama, 2003), contributing to an expanding hypoxic area (Fig. 8). It appears that changes in water renewal rate and stratification combined with increasing temperature (Fonselius and Valderrama, 2003; Omstedt et al., 2004), persistently high nutrient loads (Fig. 8), and enhanced P release from 

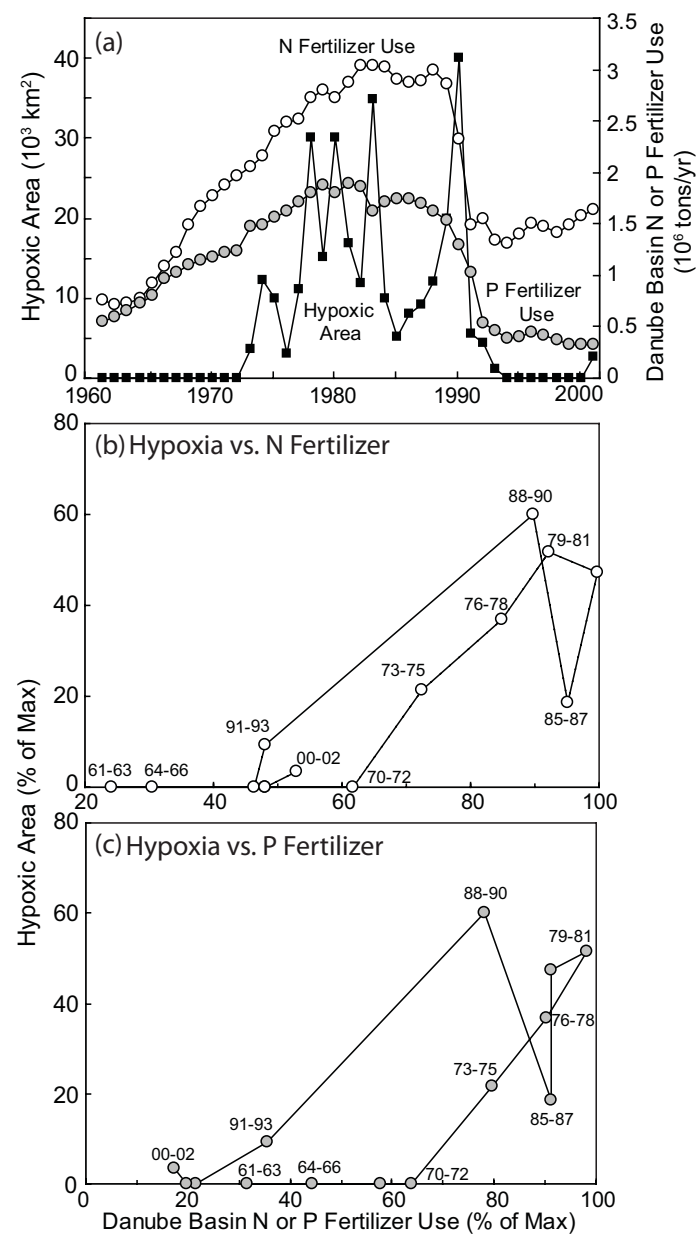

Fig. 7. (a) Time series (1960-2001) of Danube River watershed nitrogen and phosphorus fertilizer use and summer hypoxic area in the northwest shelf of the Black Sea and response trajectory of hypoxic area on the northwest shelf of the Black Sea to interannual changes in (b) nitrogen and (c) phosphorus fertilizer use derived from time series data. Data are from Mee (2006).

sediments (Conley et al., 2002, 2009a) have all contributed to stable but generally increasing hypoxic zones in this system. Despite the importance of abiotic controls on current hypoxia in the Baltic, modeling studies indicate that effective watershed nutrient management will help to reduce eutrophication and hypoxia (Wulff et al., 2007). The water volume and complex physical circulation of the Baltic suggest, however, that such a recovery would follow hysteretic pathways with long time-lags.

\subsection{Chesapeake Bay}

Chesapeake Bay is a large estuary in the United States and receives freshwater, nutrient, and organic matter inputs from several rivers, the largest of which is the Susquehanna. Dramatic ecological changes have occurred in Chesapeake Bay during the past century as a result of nutrient enrichment

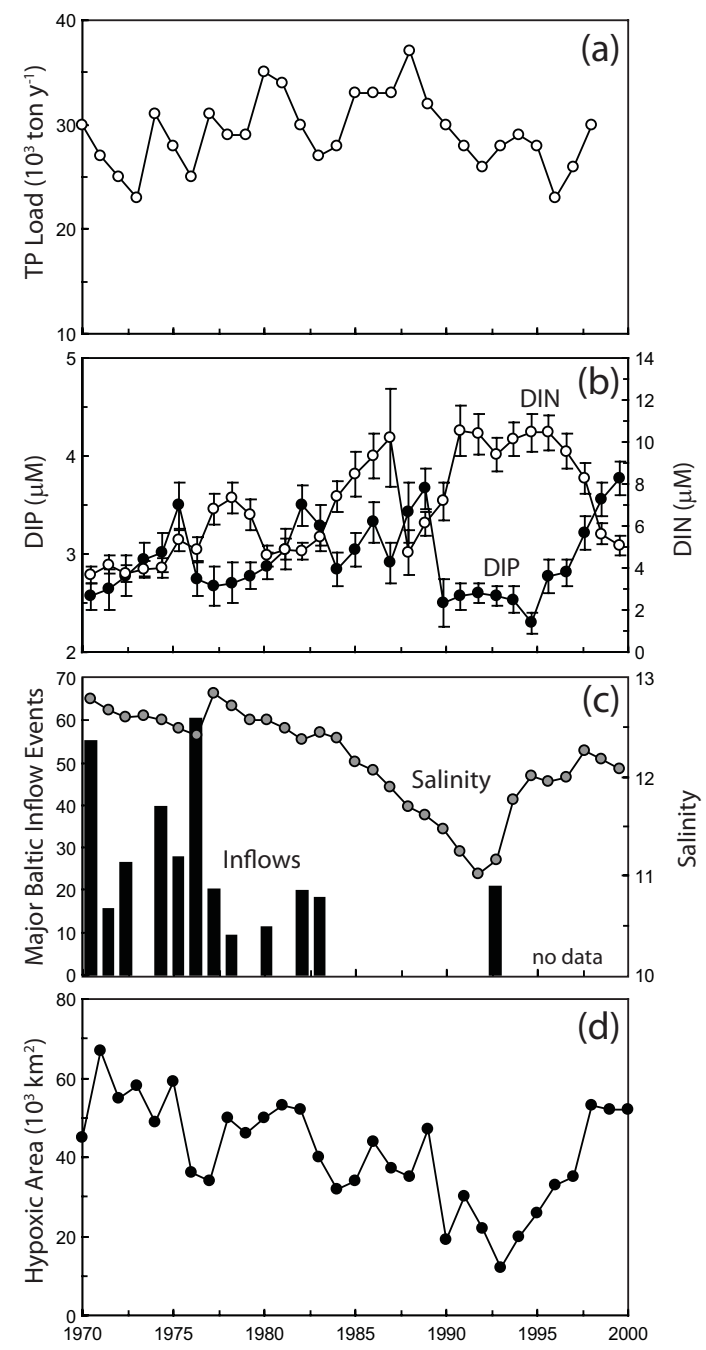

Fig. 8. Time-series (1970 to 2000) of (a) annual TP loads to the Baltic Sea (Conley et al., 2002), (b) annual concentration of DIP (solid circles) and DIN (open circles) in the Baltic Proper for depths $<100 \mathrm{~m}$ (Fonselius and Valderrama, 2003), (c) index of water inflow to the Baltic (solid bars, Schinke and Matthäus, 1998) and deep water $(200 \mathrm{~m})$ salinity (grey circles, Fonselius and Valderrama, 2003) in the Gotland Deep, and (d) hypoxic area in the Baltic Proper, Gulf of Riga, and Gulf of Finland from 1970 to 2000 (Conley et al., 2002).

driven by human population growth and land-use changes in its watershed (Kemp et al., 2005). Effects of Bay eutrophication have been compounded by extensive loss of key habitats, including tidal marshes, seagrass beds, and reefs of the filterfeeding eastern oyster, which harbor diverse animal populations and act as sinks for suspended particles and dissolved nutrients. One of the most important ecologically damaging effects of nutrient enrichment in Chesapeake Bay has been a long-term increase in the duration and volume of seasonal bottom-water hypoxia (Hagy et al., 2004). 
Because Chesapeake Bay has a large ratio of watershedto-estuary area, a deep channel isolated from the atmosphere during summer stratification, and a long water-residencetime, it is particularly susceptible to hypoxia and related effects of eutrophication (Kemp et al., 2005). Although incidents of hypoxia were reported as early as the 1930s (Newcombe and Horne, 1938), direct measurements and geochemical indicators suggest that intense and recurrent hypoxia and anoxia were uncommon before a rapid increase in nutrient loading starting in the 1950s (Hagy et al., 2004). Extensive efforts to curb nutrient enrichment of Chesapeake Bay are reflected in the stabilization and slight decline in spring nitrogen loading from the Susquehanna River since $\sim 1990$ (Fig. 9). Here we focus on N-loading because it is viewed as the primary limiting nutrient for phytoplankton production (e.g., Fisher et al., 1992, 1999). During this period of declining $\mathrm{N}$ loading, however, hypoxia volume has continued to rise (Hagy et al., 2004), resulting in an abrupt doubling of the hypoxia volume per unit spring $\mathrm{N}$ load (Fig. 5).

The cause for this unexpected shift in hypoxia volume per $\mathrm{N}$-loading is uncertain. However, it generally coincided with notable changes in several key factors that may have contributed to the hypoxia increase, including a sharp increase in water temperature, a potential decrease in nutrient retention in the upper Bay, and a rapid decrease in oyster abundance (indexed to harvest) and associated filtration capacity (Fig. 9). The rapid increase in surface water temperatures $\left(\sim 0.7^{\circ} \mathrm{C}\right)$ that occurred over two decades around 1985 (Kaushal et al., in press) would be sufficient to reduce $\mathrm{O}_{2}$ saturation level by $\sim 0.20 \mathrm{mg}^{-1}$ and possibly increase respiration by $\sim 5-10 \%$ (Sampou and Kemp, 1994). The relative abundance and filtering capacity of the eastern oyster (Crassostera virginica) in Chesapeake Bay have declined by almost 100-fold over the past 150 years due to over-fishing and two disease outbreaks (Newell, 1988; Newell and Ott, 1999; Newell et al., 2007). The drought-induced final decline in oyster harvest during the $10-15$ yr around 1985 was $~ 10 \%$ of this overall drop between 1900 and the present (Fig. 9, Kimmel and Newell, 2007). Recent modeling (Cerco and Noel, 2007) studies have concluded that 10 -fold increases in oyster filtration (equivalent to reversing the decline in the 1980s) would induce a $0.3 \mathrm{mg} \mathrm{l}^{-1}$ increase in average mid-Bay bottom water $\mathrm{O}_{2}$ concentration. The absence of any signal of increased phytoplankton corresponding to the oyster decline, however, raises some doubt about this explanation for the hypoxia shift. Other large changes in the Bay, including losses of marshes and seagrass beds, were important for Bay nutrient budgets (Kemp et al., 2005); however, they are out of phase with this abrupt increase in hypoxia.

While many of these changes in the ecosystem may have contributed to increased hypoxia in Chesapeake Bay, none appear to be sufficiently large and synchronous with hypoxia trends to have caused this hypoxia regime shift. The subpycnocline recycling of nitrogen is a key biogeochemical process that has, however, exhibited a time-course of change that parallels the hypoxia regime shift trajectory. Previous studies have suggested that as $\mathrm{O}_{2}$ decreases, a larger fraction of the total nitrogen load is recycled from sediments as $\mathrm{NH}_{4}^{+}$ and mixed vertically into the euphotic zone where it can stimulate further algal growth (see Sect. 3). This increase in $\mathrm{NH}_{4}^{+}$ recycling arises because coupled nitrification-denitrification is restricted under hypoxic conditions (Kemp et al., 1990), especially with anoxia-induced loss of benthic macrofauna (Kemp et al., 2005), which otherwise increase $\mathrm{O}_{2}$ penetration into sediments though ventilation of their tube and burrow habitats (e.g., Mayer et al., 1995). Preliminary analyses of time-series data from mid-Chesapeake Bay suggest an abrupt increase in mean summer bottom water $\mathrm{NH}_{4}^{+}$concentration per unit spring TN loading that closely follows the trend in hypoxia per $\mathrm{N}$ loading. While this analysis suggests the potential for hypoxia enhancement via benthic $\mathrm{N}$ recycling, this signal is restricted to a small area of the bay and thus it is difficult to imagine how this mechanism could have driven the observed regime shift in hypoxia per unit $\mathrm{N}$ loading.

On the other hand, abrupt changes in atmospheric forcing or continental shelf circulation might be strong enough to alter vertical or horizontal replenishment of bottom water $\mathrm{O}_{2}$ in the Bay. For example, recent modeling and data analysis suggest that sea level rise tends to cause increases in salt flux and bottom-layer salinity in Chesapeake Bay (Hilton et al., 2008), which could have increased stratification. Other evidence suggests an increase in the latitude of the north wall of the Gulf Stream since the 1980s (Taylor and Stephens, 1998) that may have reinforced the trend associated with sea level rise by causing an increase in salinity at the Bay mouth (Lee and Lwiza, 2008). A shift from negative to positive values for the winter North Atlantic Oscillation (NAO) index in the late 1970s (http://www.cgd.ucar.edu/cas/jhurrell/indices. html, Fig. 9) may be related to the change in the Gulf Stream position (Taylor and Stephens, 1998). Such a shift in NAO might also lead to changes in the prevailing wind direction and intensity during summer (Ogi et al., 2003; Scully, 2009), which could affect the strength of stratification and associated ventilation of hypoxic bottom waters in summer (e.g., Malone et al., 1986; Scully et al., 2005). Although many of the ecological and biogeochemical factors discussed here may have contributed to the initiation and resilience of this hypoxia regime shift, we conclude that physical factors are likely involved in the initiation of this change in hypoxia per $\mathrm{N}$ loading.

\subsection{Northern Gulf of Mexico}

A large region of the Gulf of Mexico's northwest continental shelf is highly influenced by outflow of the Mississippi and Atchafalaya Rivers, with associated buoyancy causing stratification and river-borne nutrient loads supporting rich phytoplankton productivity (e.g., Bianchi et al., 2008). Under present conditions, bottom-water hypoxia occurs during summer months in this northern Gulf of Mexico (NGOM) 

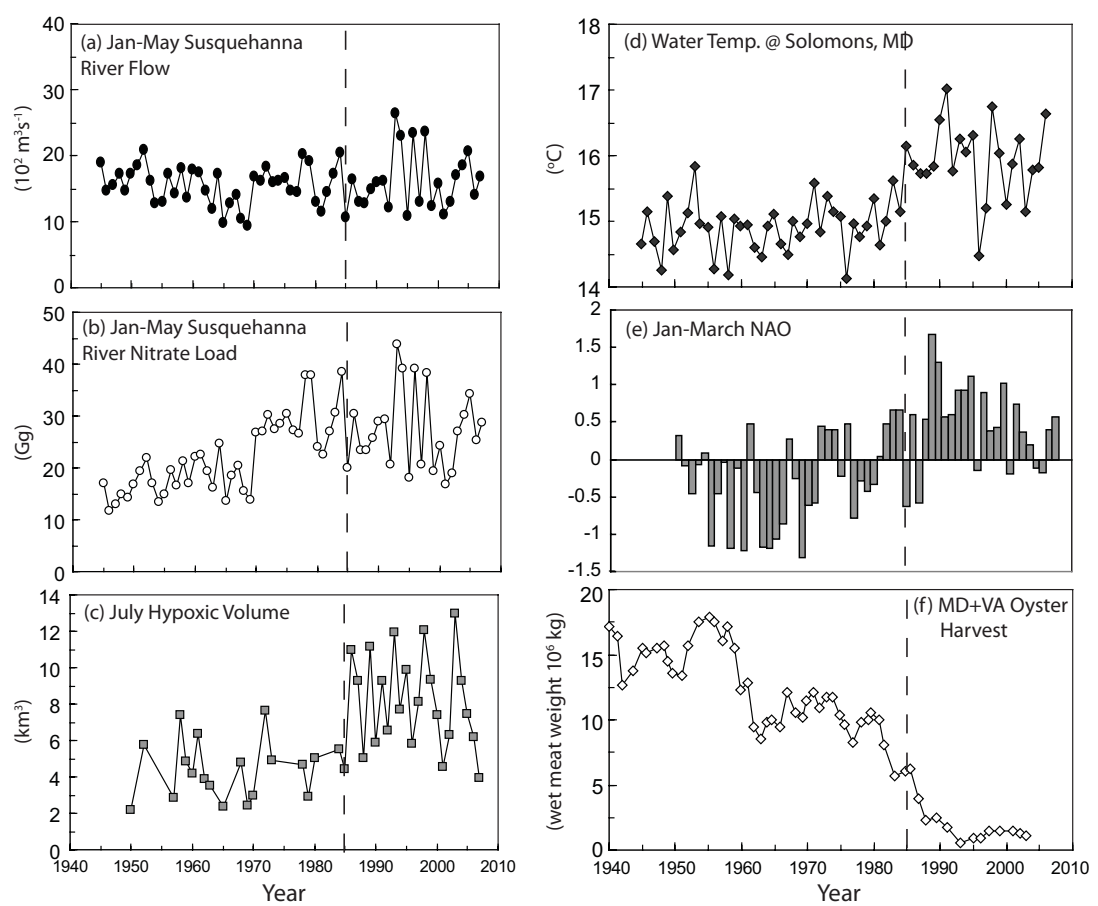

Fig. 9. Time-series (1945-2007) of (a) Susquehanna River Flow at Conowingo, MD, (b) January-May $\mathrm{NO}_{3}^{-}$loads to Chesapeake Bay, (c) July hypoxic volume in Chesapeake Bay, (d) mean annual water temperature at Solomons, MD, (e) January to March North Atlantic Oscillation, and (f) annual Maryland (MD) and Virginia (VA) oyster harvest. All data are from Kemp et al. (2005), except temperature data (Kaushal et al., 2009) and NAO data (http://www.cgd.ucar.edu/cas/jhurrell/indices.html).

region. This low- $\mathrm{O}_{2}$ zone, which was first noted in the early 1970s, has been mapped annually since the mid-1980s (e.g., Rabalais et al., 2007). Fossil records of low-oxygen-tolerant foraminifera and modeling studies, however, suggest that infrequent hypoxia probably occurred back into the 1950s (Osterman et al., 2005; Greene et al., 2009), but that large-scale hypoxic zones likely did not occur prior to the 1970s (Scavia et al., 2003; Justić et al., 2005; Turner et al., 2006b; Greene et al., 2009). A significant trend of increasing areal extent of NGOM hypoxia corresponds strongly with a parallel trend of increasing nitrogen $(\mathrm{N})$ loads from the Mississippi River (Turner et al., 2005), driven largely by the growth of intensive agricultural production in the Midwest region of the USA (Alexander et al., 2008). Since the mid-1980s, the July hypoxic zone has ranged in size from 40 to $22000 \mathrm{~km}^{2}$ and has been correlated with May $\mathrm{TN}$ and $\mathrm{NO}_{3}^{-}$loading from the Mississippi River (Scavia et al., 2004; Turner et al., 2008). A small (17\%) decrease in TN loading between 1997 and 2005 (Turner et al., 2007), however, produced no significant decrease in the extent of July hypoxia (Rabalais et al., 2007). Recent analyses have shown that, much like the situation in Chesapeake Bay, the extent of hypoxia increased substantially in 1993 and thereafter, while $\mathrm{N}$ loading has changed very little, resulting in an increase in the area of hypoxia observed per unit of $\mathrm{N}$ loading (Turner et al., 2008; Greene et al., 2009).
Although there is no clear explanation for this change in hypoxia per unit $\mathrm{N}$ loading, a range of physical and biological factors may have contributed to this hypoxia "regime shift" (Rabalais et al., 2007). Turner et al. (2008) suggested that increased sediment oxygen demand (SOD) could have caused the observed rapid increase in hypoxia. They hypothesized that intensified SOD in recent years was derived from organic matter produced in previous years but preserved and stored in sediments. They further suggested that this stored organic matter would be exposed (e.g., through resuspension events) in subsequent years to fuel enhanced respiration, thereby causing larger than expected hypoxic regions per unit $\mathrm{N}$ loading in a given year. Empirical support for this hypothesis (e.g., long-term records of SOD) is limited, and previous observations from warm marine systems suggest that the vast majority of labile organic matter produced in any year is generally respired within months (e.g., Burdige, 1991). A related hypothesis is that there has been a recent increase in organic matter inputs from sources other than the Mississippi-Atchafalaya River System (Bianchi et al., 2008). The primary postulated source for this increased organic matter input is cross-shelf transport of material from Louisiana's eroding coastal wetlands (e.g., Barras et al., 2008). Although the general magnitude of eroding wetland organic matter fluxes have been estimated, they have not been directly linked to Gulf hypoxia (Dagg et al., 2007). While 
hypoxia per $\mathrm{N}$ loading has been increasing, the rate of coastal land loss has been relatively constant (apart from hurricanedriven increases in 2005) for the last several decades (Barras et al., 2008). Others have emphasized the role of phosphorus (P) inputs in regulating NGOM hypoxia (e.g., Sylvan et al., 2006; Dagg et al., 2007). Although statistical analysis reveals that $\mathrm{N}$ loading was by far the best hypoxia predictor, inclusion of winter P levels in a multiple regression model did improve summer hypoxia predictions (e.g., Greene et al., 2009). However, the absence of long-term trends in P loading (Sylvan et al., 2006) indicates that it is not likely responsible for the observed hypoxia shift.

The general open nature of the NGOM system, with unrestricted boundaries to the south along the Gulf and to the west across the broad continental shelf, makes hypoxia development and control highly sensitive to physical circulation processes. Key physical controls on NGOM hypoxia include freshwater inflow, local meteorological forcing, and interactions with the open Gulf circulation. Of these, only the impact of freshwater flow has been considered in analyses of changes and long-term trends in the extent of hypoxia (e.g., Justić et al., 2003; Turner et al., 2005; Greene et al., 2009). One way that a change in other physical factors could impact the extent of hypoxia (and its ratio to $\mathrm{N}$ loading), is by modulating the flux of freshwater and nutrients between the shelf and open Gulf (e.g., Bianchi et al., 2006). Current estimates indicate that only $43 \%$ of the Mississippi River flow and associated nutrients enters the western shelf, whereas the remainder is directed eastward or otherwise lost to the open Gulf (Etter et al., 2004). Any change in water or nutrient transport at the shelf margin (e.g., Bianchi et al., 2006) would likely impact the extent of hypoxia independently from the riverine $\mathrm{N}$ loading rate. Summer winds are also important in regulating NGOM hypoxia, where up-coast (southwesterly) winds favor retention of freshwater (plus nutrients and plankton) on the Louisiana-Texas shelf and enhance stratification and hypoxia, until September when down-coast winds (northeasterly) promote vertical mixing and Gulf-shelf exchange (Cochrane and Kelly, 1986). Although the extent of hypoxia can be reduced quickly when frontal wind events reduce stratification (Rabalais and Turner, 2006), such events are relatively rare in summer. Clearly, changes in these physical forces are important in controlling NGOM hypoxia; however, there is no evidence to suggest decadal scale changes needed to explain the observed shift in hypoxia per unit $\mathrm{N}$ loading.

In summary, a long-term increase in the areal extent of hypoxia in the northern Gulf of Mexico since the early 1980s is linked principally to increases in N loading from the Mississippi-Atchafalaya River System. Since 1993, observed hypoxic areas have been larger than expected from spring $\mathrm{N}$ loading alone, suggesting changes in other ecological or physical drivers of hypoxia. While many alternative explanations have been suggested, no empirical evidence and/or modeling analyses have been presented to support these hypotheses. Prior to 1993, the statistical relationship between hypoxia and $\mathrm{N}$-inputs might suggest a relatively linear response to proposed reductions in Mississippi River $\mathrm{N}$-loading. However, the recently described and yet unexplained shift in this hypoxia versus $\mathrm{N}$ relationship now indicates that more complex response trajectories with hysteresis, shifting baselines, and time-lags might be anticipated.

\section{Concluding comments}

In response to the recently documented worldwide increase in eutrophication-induced cases of coastal hypoxia, we conducted this review of published case studies, focusing on temporal trajectories of hypoxia responses to changes in nutrient loading for a range of coastal systems. The purpose of this effort was to expand the knowledge-base toward improved (1) understanding of factors controlling hypoxia, (2) simulation modeling of observed hypoxia response trajectories, and (3) strategies for nutrient management to remediate coastal hypoxia. For 24 case studies published in the scientific literature, we compared observed trajectories of hypoxia response to nutrient loading to diverse patterns derived from ecological theory. Although our sample of hypoxic systems with published time series data on hypoxia, nutrients and other factors provides a rich and diverse set of examples, it appears that appropriate temporal data series may also exist (in unpublished monitoring reports) for other hypoxic coastal systems.

In general, we found that shallow well-mixed coastal systems tended to be more responsive to changes in inorganic and organic nutrient loading compared to deeper stratified estuaries and shelf regions. Most of the clearest examples of hypoxia response to loading reductions are from systems where nutrient and organic matter inputs were dominated by point sources (e.g., from sewage treatment plants). Hypoxia in vertically well-mixed coastal systems has generally responded strongly along linear or threshold trajectories to large reductions in loading of labile dissolved organic matter (BOD). Other shallow well-mixed systems have also exhibited declines in hypoxia following decreased loading of inorganic nutrients; however, responses were sometimes delayed by $5-10$ years. Even for shallow well-mixed systems, there are few published cases demonstrating hypoxia responses to reduced nutrient loading from watersheds with predominantly diffuse sources.

For deep stratified estuaries, seas or shelf systems, there are surprisingly few examples in the published literature documenting temporal responses of hypoxia to nutrient remediation. The Black Sea is the one case that is most often cited to demonstrate that large rapid reductions in nutrient loading can elicit rapid dramatic decreases in bottom-water hypoxia. Unfortunately, however, response trajectories for this example are based on proxies for $\mathrm{N}$ and $\mathrm{P}$ loading and relatively sparse measurements of $\mathrm{O}_{2}$ profiles in a very large 
system. Other deep, stratified systems, where hypoxia responses to reduced nutrient loading have been monitored generally suggest recalcitrance with respect to hypoxia improvement. Many of the best documented time series for hypoxia and nutrient loading for these stratified systems have revealed unexpected complex non-linear relationships between hypoxia extent and nutrient loading. These responses are often characterized by abrupt increases in hypoxia per unit nutrient loading that have been speculatively attributed to a range of altered internal ecosystem processes. In many instances, however, evidence is presented suggesting that changes in climatic and/or hydrodynamic conditions coincided with the observed increase in hypoxia and that these physical changes may have altered ventilation of hypoxic bottom waters or transport of nutrients to the overlying euphotic zone.

Lessons learned from this comparative analysis of hypoxia responses to changes in nutrient loading will be useful for coastal researchers and managers alike. Improved understanding of the dominant physical and biological processes is needed to characterize the natural susceptibility of specific coastal systems to hypoxia. Further information is needed concerning interactions among climatic trends and cycles, hydrodynamic circulation and mixing, biogeochemical cycles, and food-web relationships. Analyses should involve application of sophisticated statistical methods and diagnostic studies using biophysical numerical models. Remediation in smaller well-mixed systems dominated by point sources of nutrients are more likely to yield clear and immediate results compared to larger stratified systems with predominantly diffuse nutrient sources. In any case, managers will need to adopt realistic expectations regarding the speed, extent, and nature of hypoxia responses to remediation. What appears to be unsuccessful remediation may simply result from time-lags in ecological response to nutrient input reductions. Successful remediation may require combinations of nutrient loading reductions, restoration of key ecological habitats, and hydrologic engineering solutions (e.g., river flow controls). Effective sustained hypoxia remediation may require open communication among researchers, managers and stakeholders.

Acknowledgements. This work was conducted as part of the activities of the Scientific Committee on Oceanic Research (SCOR) Working Group 128 (Natural and Human-Induced Hypoxia and Consequences for Coastal Areas). We are indebted to the many individuals and agencies responsible for coastal aquatic monitoring programs, whose data make such comparative analyses possible. We would also like to thank Nancy Rabalais, Robert Díaz, and Jesper Andersen for their thoughtful reviews that greatly improved this manuscript. This work and publication costs were funded by the National Science Foundation (BES-0618986), the Department of Commerce, NOAA Coastal Hypoxia Research Program (CHRP; NA07NOS4780191), Maryland Sea Grant Program, the Climate Change Science Initiative of the Department of Fisheries and
Oceans Canada, and the SCOR Working Group 128. This is contribution No. 4365 of the University of Maryland Center for Environmental Science and NOAA Coastal Hypoxia Research Program Publication \#122.

Edited by: J. Middelburg

\section{References}

Alexander, R. B., Smith, R. A., Schwarz, G. E., Boyer, E. W., Nolan, J. V., and Brakebill, J. W.: Differences in phosphorus and nitrogen delivery to the Gulf of Mexico from the Mississippi River basin, Environ. Sci. Technol., 42, 822-830, 2008.

Aller, R. C.: The effects of macrobenthos on chemical properties of marine sediments and overlying water, in: Animal-Sediment Relations, edited by: McCall, O. P. L. and Tevesz, M. J. S., Plenum Press, New York, 3-52, 1982.

Andrews, M. J. and Rickard, D. G.: Rehabilitation of the inner Thames Estuary, Mar. Pollut. Bull., 11, 327-332, 1980.

Arhonditsis, G. B. and Brett, M. T.: Evaluation of the current state of mechanistic aquatic biogeochemical modeling, Mar. Ecol.Prog. Ser., 271, 13-26, 2004.

Arnell, N. W.: The effect of climate change on hydrological regimes in Europe: A continental perspective, Global Environ. Chang., 9, 5-23, 1999.

Baird, D., Christian, R. R., Peterson, C. H., and Johnson, G. A.: Consequences of hypoxia on estuarine ecosystem function: Energy diversion from consumers to microbes, Ecol. Appl., 14, 805-822, 2004.

Balls, P. W., Brockie, N., Dobson, J., and Johnston, W.: Dissolved oxygen and nitrification in the upper Forth Estuary during summer (1982-1992): Patterns and trends, Estuar. Coast. Shelf S., 42, 117-134, 1996.

Banas, N. S., Hickey, B., Newton, J., and Ruesink, J.: Tidal exchange, bivalve grazing, and patterns of primary production in Willapa Bay, Washington, USA, Mar. Ecol.-Prog. Ser., 34, 123139, 2007.

Barras, J. A., Bernier, J. C., and Morton, R. A.: Land area change in coastal Louisiana - A multidecadal perspective (from 1956 to 2006): U.S. Geological Survey Scientific Investigations Map 3019, scale 1:250000, 14 pp. pamphlet, 2008.

Behrendt, H., van Gils, J., Schreiber, H., and Zessnex, M.: point and diffuse nutrient emissions and loads in the transboundary Danube River basin. II. Long-term changes, Arch. Hydrobiol. Suppl. 158/1-2, Large Rivers, 16(1-2), 221-247, 2005.

Bianchi, T. S., Allison, M. A., Canuel, E. A., Corbett, D. R., McKee, B. A., Sampere, T. P., Wakeham, S. G., and Waterson, E.: Rapid export of organic matter to the Mississippi Canyon, EOS T. Am. Geophys. Un., 87, 565, 572-573, 2006.

Bianchi, T. S.: Biogeochemistry of Estuaries, Oxford University Press, Oxford, 2007.

Bianchi, T. S., DiMarco, S., Allison, M., Chapman, P., Cowan, J., Hetland, R., and Morse, J. W.: Controlling hypoxia on the U.S. Louisiana shelf: beyond the nutrient-centric view, EOS T. Am. Geophys. Un., 89, 236-237, 2008.

Boesch, D. F., Brinsfield, R. B., and Magnien, R. E.: Chesapeake Bay eutrophication: Scientific understanding, ecosystem restoration, and challenges for agriculture, J. Environ. Qual., 30, 303320, 2001. 
Borja, A., Muxika, I., and Franco, J.: Long-term recovery of softbottom benthos following urban and industrial sewage treatment in the Nervion estuary (southern Bay of Biscay), Mar. Ecol.Prog. Ser., 313, 43-44, 2006.

Borsuk, M. E., Stow, C. A., Luettich Jr., R. A., Paerl, H. W., and Pinckney, J. L.: Modelling oxygen dynamics in an intermittently stratified estuary: Estimation of process rates using field data, Estuar. Coast. Shelf S., 52, 33-49, 2001.

Boicourt, W. C.: Influences of circulation processes on dissolved oxygen in the Chesapeake Bay, in: Oxygen Dynamics in the Chesapeake Bay, A Synthesis of Recent Research, edited by: Smith, D. E., Leffler, M., and Mackiernan, G., Maryland Sea Grant, College Park, MD, 7-59, 1992.

Boynton, W. R., Hagy, J., Cornwell, J., Kemp, W. M., Greene, S., Owens, M., Baker, J., and Larsen, R.: Nutrient budgets and management actions in the Patuxent River estuary, Maryland, Estuaries Coasts, 31, 623-651, 2008.

Breitburg, D.: Effects of hypoxia, and the balance between hypoxia and enrichment, on coastal fishes and fisheries, Estuaries, 25, 767-781, 2002.

Bricker, S. B. and Stevenson, J. C.: Nutrients in coastal waters: A chronology and synopsis of research, Estuaries, 19, 337-341, 1996.

Brosnan, T. M. and O'Shea, M. L.: Long-term improvements in water quality due to sewage abatement in the lower Hudson River, Estuaries, 19, 890-900, 1996.

Burdige, D. J.: The kinetics of organic matter mineralization in anoxic marine sediments, J. Mar. Res., 49, 727-761, 1991.

Caraco, N. F., Cole, J. J., and Likens, G. E.: Evidence for sulfatecontrolled phosphorus release from sediments of aquatic systems, Nature, 341, 316-318, 1989.

Carpenter, S. R. and Lathrop, R. C.: Probabilistic estimate of a threshold for eutrophication, Ecosystems, 11, 601-613, 2008.

Carstensen, J., Conley, D. J., Andersen, J., and Aertebjerg, G.: Coastal eutrophication and trend reversal: A Danish case study, Limnol. Oceanogr., 51, 398-408, 2006.

Cerco, C. F. and Noel, M. R.: Can oyster restoration reverse cultural eutrophication in Chesapeake Bay?, Estuaries Coasts, 30, 331343, 2007.

Chan, F., Barth, J. A., Lubchenco, J., Kirincich, A., Weeks, H., Peterson, W. T., and Menge, B. A.: Emergence of anoxia in the California current large marine ecosystem, Science, 319, p. 920, 2008.

Chen, C.-C., Gong, G.-C., and Shiah, F.-K.: Hypoxia in the East China Sea: One of the largest coastal low-oxygen areas in the world, Mar. Environ. Res., 64, 399-408, 2007.

Chen, C.-C., Shiah, F.-K., Chaing, K.-P., Gong, G.-C., and Kemp, W. M.: Effects of the Changjiang (Yangtze) River discharge on planktonic community respiration in the East China Sea, J. Geophys. Res., 114, 1-15, doi:10.1029/2008JC004891.2009, 2009.

Cochrane, J. D. and Kelly, F. J.: Low-frequency circulation on the Texas-Louisiana continental shelf, J. Geophys. Res., 91, 1064510659, 1986.

Conley, D. J., Humborg, C., Rahm, L., Savchuk, O. P., and Wulff, F.: Hypoxia in the Baltic Sea and basin-scale changes in phosphorus biogeochemistry, Environ. Sci. Technol., 36, 5315-5320, 2002.

Conley, D. J., Carsetnsen, J., Ærtebjerg, G., Christensen, P. B., Dalsgaard, T., Hansen, J., and Josefson, A.: Long-term changes and impacts of hypoxia in Danish coastal waters, Ecol. Appl., 17, S165-S184, 2007.

Conley, D. J., Björck, S., Bonsdorff, E., Carstensen, J., Destouni, G., Gustafsson, B. G., Hietanen, S., Kortekaas, M., Kuosa, H., Meier, H. E. M., Müller-Karulis, B., Nordberg, K., Norkko, A., Nürnberg, G., Pitkänen, H., Rabalais, N. N., Rosenberg, R., Savchuk, O. P., Slomp, C. P., Voss, M., Wulff, F., and Zillén, L.: Hypoxia-related processes in the Baltic Sea, Environ. Sci. Technol., 43, 3412-3420, 2009a.

Conley, D. J., Carstensen, J., Vaquer-Sunyer, R., and Duarte, C. M.: Ecosystem thresholds with hypoxia, Hydrobiologia, 629, 21-29, 2009b.

Conley, D. J., Bonsdorff, E., Carstensen, J., Destouni, G., Gustafsson, B. G., Hansson, L.-A., Rabalais, N. N., Voss, M., and Zillén, L.: Tackling hypoxia in the Baltic Sea: Is engineering a solution?, Environ. Sci. Tech., 43, 3407-3411, 2009c.

Cox, T. J. S., Maris, T., Soetaert, K., Conley, D. J., Van Damme, S., Meire, P., Middelburg, J. J., Vos, M., and Struyf, E.: A macrotidal freshwater ecosystem recovering from hypereutrophication: the Schelde case study, Biogeosciences, 6, 2935-2948, 2009, http://www.biogeosciences.net/6/2935/2009/.

Dame, R. F. and Prins, T. C.: Bivalve carrying capacity in coastal ecosystems, Aquat. Ecol., 31, 409-421, 1998.

Dame, R. F. and Olenin, S.: The comparative roles of suspension feeders in ecosystems, NATO ASI Sci. Ser. 4 Earth Environmental Science, Springer-Verlag, Berlin, 2005.

Dagg, M. J., Ammerman, J. W., Amon, R. M. W., Gardner, W. S., Green, R. E., and Lohrenz, S. E.: A review of water column processes influencing hypoxia in the northern Gulf of Mexico, Estuaries Coasts, 30, 735-752, 2007.

D'Avanzo, C. and Kremer, J. N.: Diel oxygen dynamics and anoxic events in an eutrophic estuary of Waquoit Bay, Massachusetts, Estuaries, 17, 131-139, 1994.

Darby, F. A. and Turner, R. E.: Effects of eutrophication on salt marsh root and rhizome biomass accumulation, Mar. Ecol.-Prog. Ser., 363, 63-70, 2008.

Decker, M. B., Breitburg, D. L., and Purcell, J. E.: Effects of low dissolved oxygen on zooplankton predation by the ctenophore Mnemiopsis leidyi, Mar. Ecol.-Prog. Ser., 280, 163-172, 2004.

de Jonge, V. N.: High remaining productivity in the Dutch western Wadden Sea despite decreasing nutrient inputs from riverine sources, Mar. Poll. Bull., 34, 427-436, 1997.

De Vries, I., Duin, R., Peeters, J., Los, F., Bokhorst, M., and Laane, R.: Patterns and trends in nutrient and phytoplankton in Dutch coastal waters: Comparison of time-series analysis, ecological model simulation, and mesocosm experiments, ICES J. Mar. Sci., 55, 620-624, 1998.

D’Elia, C. F., Boynton, W. R., and Sanders, J. G.: A watershed perspective on nutrient enrichment, science, and policy in the Patuxent River, Maryland: 1960-2000, Estuaries, 26, 171-185, 2003.

Díaz, R. J. and Rosenberg, R.: Marine benthic hypoxia: A review of its ecological effects and the behavioral responses of benthic macrofauna, Oceanogr. Mar. Biol., 33, 245-303, 1995.

Díaz, R. J.: Overview of hypoxia around the world, J. Environ. Qual., 30, 275-281, 2001.

Díaz, R. J., Rhoads, D. C., Blake, J. A., Kropp, R. K., and Keay, K. E.: Long-term trends of benthic habitats related to reduction in wastewater discharge to Boston Harbor, Estuaries Coasts, 31, 
1184-1197, 2008.

Díaz, R. J. and Rosenberg, R.: Spreading dead zones and consequences for marine ecosystems, Science, 321, 926-929, 2008.

Di Toro, D. M.: Sediment flux modeling, John Wiley, New York, 2001.

Duarte, C. M.: Seagrass nutrient content, Mar. Ecol.-Prog. Ser., 67, 201-207, 1990.

Duarte, C. M., Conley, D. J., Carstensen, J., and Sanchez-Camacho, J.: Return to "Neverland": Shifting baselines affect eutrophication restoration targets, Estuaries Coasts, 32, 29-36, 2009.

Etter, P. C., Howard, M. K., and Cochrane, J. D.: Heat and freshwater budgets of the Texas-Louisiana shelf, J. Geophys. Res., 109, C02024, doi:10.1029/2003JC001820, 2004.

Fallesen, G., Andersen, F., and Larsen, B.: Life, death and revival of the hypertrophic Mariager Fjord, Denmark, J. Marine Syst., 25, 313-321, 2000.

Fisher, T. R., Peele, E. R., Ammerman, J. W., and Harding Jr., L. W.: Nutrient limitation of phytoplankton in Chesapeake Bay, Mar. Ecol.-Prog. Ser., 82, 51-63, 1992.

Fisher, T. R., Gustafson, A. B., Sellner, K., Lacouture, R., Haas, L. W., Wetzel, R. L., Magnien, R., Everitt, D., Michaels, B., and Karrh, R.: Spatial and temporal variation of resource limitation in Chesapeake Bay, Mar. Biol., 133, 763-778, 1999.

Fonselius, S. and Valderrama, J.: One hundred years of hydrographic measurements in the Baltic Sea, J. Sea Res., 49, 229 $241,2003$.

Francois, F., Poggiale, J., Durbec, J., and Stora, G.: A new model of bioturbation for a functional approach to sediment reworking resulting from macrobenthic communities, In: Organism-Sediment Interactions, edited by: Aller, J. Y., Woodin, S. A., and Aller, R.C ., University of South Carolina Press, Columbia, SC, 73-86, 2001.

Froelich, P. N., Bender, M. L., and Luedtke, N. A.: The marine phosphorus cycle, Am. J. Sci., 282, 474-511, 1982.

Froelich, P. N.: Kinetic control of dissolved phosphate in natural rivers and estuaries: A primer on the phosphate buffer mechanisms, Limnol. Oceanogr., 33, 649-668, 1988.

Gilbert, D., Sundby, B., Gobeil, C., Mucci, A., and Tremblay, G.H.: A seventy-two-year record of diminishing deep-water oxygen in the St. Lawrence estuary: The northwest Atlantic connection, Limnol. Oceanogr., 50, 1654-1666, 2005.

Gilbert, D., Rabalais, N. N., Diaz, R. J., and Zhang, J.: Evidence for greater oxygen decline rates in the coastal ocean than in the open ocean, Biogeosciences Discuss., 6, 9127-9160, 2009, http://www.biogeosciences-discuss.net/6/9127/2009/.

Greene, R. M., Legrter, J. C., and Hagy, J. D.: Multiple regression models for hindcasting and forecasting midsummer hypoxia in the Gulf of Mexico, Ecol. Appl., 19, 1161-1175, 2009.

Hagy, J. D., Boynton, W. R., Keefe, C. W., and Wood, K. V.: Hypoxia in Chesapeake Bay, 1950-2001: Long-term change in relation to nutrient loading and river flow, Estuaries, 27, 634-658, 2004.

Hagy, J. D., Boynton, W. R., and Jasinski, D.: Modeling phytoplankton deposition to Chesapeake Bay sediments during winter-spring: Interannual variability in relation to river flow, Estuar. Coast. Shelf S., 62, 25-40, 2005.

Hagy, J. D. and Murrell, M. C.: Susceptibility of a northern Gulf of Mexico estuary to hypoxia: An analysis using box models, Estuar. Coast. Shelf S., 74, 239-253, 2007.
Harding Jr., L. W. and Perry, E. S.: Long-term increase of phytoplankton biomass in Chesapeake Bay, 1950-1994, Mar. Ecol.Prog. Ser., 157, 39-52, 1997.

Hedges, J.I. and Keil, R.G.: Sedimentary organic matter preservation: An assessment and speculative synthesis, Mar. Chem., 49, 81-115, 1995.

Helly, J. J. and Levin, L. A.: Global distribution of naturally occurring marine hypoxia on continental margins, Deep-Sea Res.I., 51, 1159-1168, 2004.

Henriksen, K. and Kemp, W. M.: Nitrification in estuarine and coastal marine sediments: Methods, patterns and regulating factors, in: Nitrogen Cycling in Coastal Marine Environments, edited by: Blackburn, T. H. and Sørensen, J., John Wiley, New York, 207-209, 1988.

Henriksen, P.: Long-term changes in phytoplankton in the Kattegat, the Belt Sea, the Sound, and the western Baltic Sea, J. Sea Res., 61, 114-123, 2009.

Hilton, T. W., Najjar, R. G., Zhong, L., and Li, M.: Is there a signal of sea-level rise in Chesapeake Bay salinity?, J. Geophys. Res., 113, C09002, doi:10.1029/2007JC004247, 2008.

Holgate, S. J. and Woodworth, P. L.: Evidence for enhanced coastal sea level rise during the 1990s, Geophys. Res. Lett., 31, L07305, doi:10.1029/2004GL019626, 2004.

Hopkinson, C. S. and Smith, E. M.: Estuarine respiration: an overview of benthic, pelagic, and whole system respiration, in: Respiration in Aquatic Ecosystems, edited by: del Giorgio, P. and Williams, P. J. le B., Oxford University Press, Oxford, 122146, 2005.

Jeppesen, E., Sondergaard, M., Pedersen, A., Jurgens, K., Strzelczak, A., Lauridsen, T., and Johansson, L.: Salinity induced regime shift in shallow brackish lagoons, Ecosystems, 10, 4757, 2007.

Jones, P. D.: Water quality and fisheries in the Mersey estuary, England: A historical perspective, Mar. Pollut. Bull., 53, 144-154, 2006.

Jonsson, P., Carman, R., and Wulff, F.: Laminated sediments in the Baltic: A tool for evaluating nutrient mass balances, Ambio, 19, 152-158, 1990.

Jordan, T. E., Correll, D. L., Miklas, J., and Weller, D. E.: Longterm trends in estuarine nutrients and chlorophyll, and short-term effects of variation in watershed discharge, Mar. Ecol.-Prog. Ser., 75, 121-132, 1991.

Joye, S. B. and Hollibaugh, J. T.: Influence of sulfide inhibition of nitrification on nitrogen regeneration in sediments, Science, 270, 623-625, 1995.

Justić, D., Turner, R. E., and Rabalais, N. N.: Climatic influences on riverine nitrate flux: Implications for coastal marine eutrophication and hypoxia, Estuaries, 26, 1-11, 2003.

Justić, D., Rabalais, N. N., and Turner, R .E.: Coupling between climate variability and coastal eutrophication: Evidence and outlook for the northern Gulf of Mexico, J. Sea. Res., 54, 25-35, 2005.

Kauppila, P., Weckström, K., Vaalgamaa, S., Korhola, A., Pitkänen, H., Reuss, N., and Drew, S.: Tracing pollution and recovery using sediments in an urban estuary, northern Baltic Sea: Are we far from ecological reference conditions?, Mar. Ecol.-Prog. Ser., 290, 35-53, 2005.

Kaushal, S. S, Likens, G. E., Jaworski, N. A., Pace, M. L., Sides, A. M., Seekell, D., Belt, K. T., Secor, D. H., and Wingate, R.: 
Rising stream and river temperatures in the United States, Front. Ecol. Environ., in press, 2009.

Kemp, W. M., Sampou, P. A., Caffrey, J. M., Mayer, M., Henriksen, K., and Boynton, W. R.: Ammonium recycling versus denitrification in Chesapeake Bay sediments, Limnol. Oceanogr., 35, 1545-1563, 1990.

Kemp, W. M., Sampou, P. A., Garber, J., Tuttle, J., and Boynton, W. R.: Seasonal depletion of oxygen from bottom waters of Chesapeake Bay: Roles of benthic and planktonic respiration and physical exchange processes, Mar. Ecol.-Prog. Ser., 85, 137$152,1992$.

Kemp, W. M., Boynton, W. R., Adolf, J., Boesch, D., Boicourt, W., Brush, G., Cornwell, J., Fisher, T., Glibert, P., Hagy, J., Harding, L., Houde, E., Kimmel, D., Miller, W. D., Newell, R. I. E., Roman, M., Smith, E., and Stevenson, J. C.: Eutrophication of Chesapeake Bay: Historical trends and ecological interactions, Mar. Ecol.-Prog. Ser., 303, 1-29, 2005.

Kimmel, D. K. and Newell, R. I. E.: The influence of climate variation on eastern oyster (Crassostrea virginica) juvenile abundance in Chesapeake Bay, Limnol. Oceanogr., 52, 959-965, 2007.

Kronvang, B., Jeppesen, E., Conley, D., Søndergaard, M., Larsen, S., Ovesen, N., and Carstensen, J.: Nutrient pressures and ecological responses to nutrient loading reductions in Danish streams, lakes and coastal waters, J. Hydrol., 304, 274-288, 2005.

Kuo, A. Y., Park, K., and Mustafa, M. Z.: Spatial and temporal variabilities of hypoxia in Rappahannock River, Virginia, Estuaries, 14, 113-121, 1991.

Lancelot, C., Staneva, J., Van Eeckhout, D., Beckers, J.-M., and Stanev, E.: Modelling the Danube-influenced north-western continental shelf of the Black Sea. II: Ecosystem response to changes in nutrient delivery by the Danube River after its damming in 1972, Estuar. Coast. Shelf S., 54, 473-499, 2002.

Lee, Y. J. and Lwiza, K.: Interannual variability of temperature and salinity in shallow water: Long Island Sound, New York, J. Geophys. Res., 110, C09022, doi:10.1029/2004JC002507, 2005.

Levin, L. A.: Oxygen minimum zone benthos: Adaptation and community response to hypoxia, Oceanogr. Mar. Biol., 41, 1-45, 2003.

Lin, J., Xu, H., Cudaback, C., and Wang, D.: Inter-annual variability of hypoxic conditions in a shallow estuary, J. Marine Syst., 73, 169-184, 2008.

MacPherson, T. A., Cahoon, L., and Mallin, M.: Water column oxygen demand and sediment oxygen flux: patterns of oxygen depletion in tidal creeks, Hydrobiologia, 586, 235-248, 2007.

Mallin, M. A., McIver, M., Wells, H., Parsons, D., and Johnson V.: Reversal of eutrophication following sewage treatment upgrades in the New River estuary, North Carolina, Estuaries, 28, 750760,2005

Malone, T. C., Kemp, W. M., Ducklow, H. W., Boynton, W. R., Tuttle, J. H., and Jonas, R. B.: Lateral variation in the production and fate of phytoplankton in a partially stratified estuary, Mar. Ecol.-Prog. Ser., 32, 149-160, 1986.

Mayer, M. S., Shaffner, L., and Kemp W. M.: Nitrification potentials of benthic macrofaunal tubes and burrow walls: Effects of sediment $\mathrm{NH}_{4}^{+}$and animal irrigation behavior, Mar. Ecol.-Prog. Ser., 121, 157-169. 1995.

Mee, L.: Reviving dead zones, Sci. Am., 295, 78-85, 2006.
Middelburg, J. J. and Levin, L. A.: Coastal hypoxia and sediment biogeochemistry, Biogeosciences, 6, 1273-1293, 2009, http://www.biogeosciences.net/6/1273/2009/.

Møhlenberg, F.: Effect of meteorology and nutrient load on oxygen depletion in a Danish micro-tidal estuary, Aquat. Ecol., 33, 5564, 2009.

Najjar, R. G., Walker, H. A., Anderson, P. J., Barron, E. J., Bord, R. J., Gibson, J. R., Kennedy, V. S., Knight, C. G., Megonigal, J. P., O'Connor, R. E., Polsky, C. D., Psuty, N. P., Richards, B. A., Sorenson, L. G., Steele, E. M., and Swanson, R. S.: The potential impacts of climate change on the mid-Atlantic coastal region, Clim. Res., 14, 219-233, 2000.

Najjar, R., Pyke, C., Adams, M. B., Breitburg, D., Hershner, C., Kemp, W. M., Howarth, R., Mulholland, M., Paolisso, M., Secor, D., Sellner, K., Wardrop, D., and Wood, R.: Potential climatechange impacts on the Chesapeake Bay, Estuar. Coast. Shelf S., doi:10.1016/j.ecss.2009.09.026, in press, 2009.

Nestlerode, J. A. and Díaz, R. J.: Effects of periodic environmental hypoxia on predation of a tethered polychaete, Glycera americana: Implication for trophic dynamics, Mar. Ecol.-Prog. Ser., 172, 185-195, 1998.

Newcombe, C. L. and Horne, W. A.: Oxygen-poor waters in the Chesapeake Bay, Science, 88, 80-81, 1938.

Newcombe, C. L., Horne, W. A., and Shepherd, B. B.: Studies on the physics and chemistry of estuarine waters in Chesapeake Bay, J. Mar. Res., 2, 87-116, 1939.

Newell, R. I. E.: Ecological Changes in Chesapeake Bay: Are they the result of overharvesting the Eastern oyster (Crassostrea virginica)?, in: Understanding the Estuary: Advances in Chesapeake Bay Research, edited by: Lynch, M. P. and Krome, E. C., Chesapeake Research Consortium Publication 129 (CBP/TRS 24/88), Gloucester Point, Virginia, 536-546, 1988.

Newell, R., and Ott, J.: Macrobenthic Communities and Eutrophication, in: Ecosystems at the Land-Sea Margin: Drainage Basin to Coastal Sea, edited by: Malone, T. C., Malej, A., Harding Jr., L. W., Smodlaka, N., and Turner, R. E., Coastal and Estuarine Studies Vol. 55. American Geophysical Union, Washington, DC, 265-293, 1999.

Newell, R. I. E., Fisher, T. R., Holyoke, R. R., and Cornwell, J. C.: Influence of eastern oysters on nitrogen and phosphorus regeneration in Chesapeake Bay, USA. In: The Comparative Roles of Suspension Feeders in Ecosystems, edited by: Dame, R. and Olenin, S., NATO Science Series: IV - Earth and Environmental Sciences V. 47, Springer, The Netherlands, 93-120, 2005.

Newell, R. I. E., Kemp, W. M., Hagy, J. D., Cerco, C. F., Testa, J. M., and Boynton, W. R.: Top-down control of phytoplankton by oysters in Chesapeake Bay, USA: Comment on Pomeroy et al. (2006), Mar. Ecol.-Prog. Ser., 341, 293-298, 2007.

Nixon, S. W., Granger, S., Buckley, B. A., Lamont, M., and Rowell, B.: A one hundred and seventeen year coastal water temperature record from Woods Hole, Massachusetts, Estuaries, 27, 397-404, 2004.

O’Donnell, J. H., Dam, H. G., Bohlen, W. F., Fitzgerald, W., Gray, P. S., Houk, A. E., Cohen, D. C., and Howard-Strobel, M. M.: Intermittent ventilation in the hypoxic zone of western Long Island Sound during the summer of 2004, J. Geophys. Res., 113, 1-13, 2008.

Officer, C. B., Biggs, R., Taft, J. L., Cronin, L. E., Tyler, M., and Boynton, W. R.: Chesapeake Bay anoxia: Origin, development, 
and significance, Science, 223, 22-27, 1984.

Ogi, M., Tachibana, Y., and Yamazaki, K.: Impact of the wintertime North Atlantic Oscillation (NAO) on the summertime atmospheric circulation, Geophys. Res. Lett., 30, 1704, doi:10.1029/2003GL017280, 2003.

Oguz, T. and Gilbert, D.: Abrupt transitions of the top-down controlled Black Sea pelagic ecosystem during 1960-200: Evidence for regime-shifts under strong fishery exploitation and nutrient enrichment modulated by climate-induced variations, Deep-Sea Res. I, 54, 220-242, 2007.

Omstedt, A., Pettersen, C., Rodhe, J., and Winsor, P.: Baltic Sea climate: $200 \mathrm{yr}$ of data on air temperature, sea level variation, ice cover, and atmospheric circulation, Climate Res., 25, 205216, 2004.

Orth, R., Carruthers, T., Dennison, W., Duarte, C., Fourqurean, J., Heck, K., Hughes, R., Kendrick, G., Kenworthy, J., Olyarnik, S., Short, F., Waycott, M., and Williams, S.: A global crisis for seagrass ecosystems, BioScience, 56, 987-996, 2006.

O'Shea, M. L. and Brosnan, T.: Trends in indicators of eutrophication in western Long Island Sound and the Hudson-Raritan estuary, Estuaries, 23, 877-901, 2000.

Osterman, L. E., Poore, R., Swarzenski. P., and Turner, R. E.: Reconstructing a 180-yr record of natural and anthropogenic induced low- oxygen conditions from Louisiana continental shelf sediments, Geology, 33, 329-333, 2005.

Paerl, H. W., Valdes, L., Joyner, A., and Piehler, M.: Solving problems resulting from solutions: Evolution of a dual nutrient management strategy for the eutrophying Neuse River estuary, North Carolina, Environ. Sci. Technol., 38, 3068-3073, 2004.

Park, K., Kim, C.-K., and Schroeder, W. W.: Temporal variability in summertime bottom hypoxia in shallow areas of Mobile Bay, Alabama, Estuaries Coasts, 31, 54-65, 2007.

Parker, C. A. and O'Reilly, J. E.: Oxygen depletion in Long Island Sound: A historical perspective, Estuaries, 14, 248-264, 1991.

Patrick, R.: Changes in the chemical and biological characteristics of the upper Delaware River estuary in response to environmental laws, in: Ecology and Restoration of the Delaware River Basin, edited by: Majumdar, S. K., Miller, E. W., and Sage L. E., The Philadelphia Academy of Science, Philadelphia, Pennsylvania, 332-359. 1988.

Peierls, B. L., Christian, R. R., and Paerl, H. W.: Water quality and phytoplankton as indicators of hurricane impacts on a large estuarine ecosystem, Estuaries, 26, 1329-1343, 2003.

Pelegri, S. P. and Blackbrun, T. H.: Effect of bioturbation by Nereis sp., Mya arenaria and Cerastoderma sp., on nitrification and denitrification in estuarine sediments, Ophelia, 42, 289-299, 1995.

Petersen, J. K., Hansen, J. W., Laursen, M. B., Clasuen, P., Carstensen, J., and Conley, D. J.: Regime shift in a coastal marine ecosystem, Ecol. Appl., 18, 497-510, 2008.

Pyke, C. R., Najjar, R. G., Adams, M. B., Breitburg, D., Kemp, W. M., Hershner, C., Howarth, R., Mulholland, M., Paolisso, M., Secor, D., Sellner, K., Wardrop, D., and Wood, R.: Climate change and the Chesapeake Bay: State-of-the-Science Review and Recommendations. A Report from the Chesapeake Bay Program Science and Technical Advisory Committee (STAC), Annapolis, MD, 2008.

Pomeroy, L. R., D'Elia, C. F., and Schaffner, L. C.: Limits to topdown control of phytoplankton by oysters in Chesapeake Bay,
Mar. Ecol.-Prog. Ser., 325, 301-309, 2006.

Prins, T. C., Smaal, A., and Dame, R.: A review of the feedbacks between bivalve grazing and ecosystem processes, Aquat. Ecol., 31, 349-359, 1998.

Purcell, J. E. and Decker, M. B.: Effects of climate on relative predation by scyphomedusae and ctenophores on copepods in Chesapeake Bay during 1987-2000, Limnol. Oceanogr., 50, 376-387, 2005.

Rabalais, N. N. and Turner, R. E.: Oxygen depletion in the Gulf of Mexico adjacent to the Mississippi River, in: Past and Present Marine Water Column Anoxia, edited by: Neretin, L. N., NATO Science Series: IV-Earth and Environmental Sciences, Kluwer Academic Publishers, Dordrect, The Netherlands, 222245, 2006.

Rabalais, N. N., Turner, R. E., Sen Gupta, B. K., Boesch, D. F., Chapman, P., and Murrell, M. C.: Hypoxia in the northern Gulf of Mexico: Does the science support the plan to reduce, mitigate, and control hypoxia?, Estuaries Coasts, 30, 753-772, 2007.

Rabalais, N. N. and Gilbert, D.: Distribution and consequences of hypoxia, in: Watersheds, Bays and Bounded Seas, edited by: Urban, E., Sundby, B., Malanotte-Rizzoli, P., and Melillo J. M., Island Press, Washington, DC, 209-226, 2009.

Rabalais, N. N., Díaz, R. J., Levin, L. A., Turner, R. E., Gilbert, D., and Zhang, J.: Dynamics and distribution of natural and humancaused coastal hypoxia, Biogeosciences Discuss., 6, 9359-9453, 2009 , http://www.biogeosciences-discuss.net/6/9359/2009/.

Reish, D. J.: The seasonal settlement of polychaete larvae before and after pollution abatement in Los Angeles-Long Beach harbors, California, B. Mar. Sci., 67, p. 672, 2000.

Revsbech, N. P., Risgaard-Petersen, N., Schramm, A., and Nielsen, L. P.: Nitrogen transformations in stratified aquatic microbial ecosystems, A. Van Leeuw, J. Microb., 90, 361-375, 2006.

Roman, M. R. and Gauzens, A.: Copepod grazing in the equatorial Pacific, Limnol. Oceanogr., 42, 623-634, 1997.

Sampou, P. A. and Kemp, W. M.: Factors regulating plankton community respiration in Chesapeake Bay, Mar. Ecol.-Prog. Ser. 110, 249-258, 1994.

Scavia, D., Rabalais, N. N., Turner, R. E., Justić, D., and Wiseman, W. J.: Predicting the response of Gulf of Mexico hypoxia to variations in Mississippi River nitrogen load, Limnol. Oceanogr., 48, 951-956, 2003.

Scavia, D., Justić, D., and Bierman Jr., V. J. : Reducing hypoxia in the Gulf of Mexico: Advice from three models, Estuaries, 27, 419-425, 2004.

Scheffer, M., Carpenter, S., Foley, J. A., Folke, C., and Walker, B.: Catastrophic shifts in ecosystems, Nature, 413, 591-596, 2001.

Scheffer, M. and Jeppesen, E.: Regime shifts in shallow lakes, Ecosystems, 10, 1-3, 2007.

Schinke, H. and Matthäus, W.: On the causes of major Baltic inflows - an analysis of long time series, Cont. Shelf Res., 18, 6797, 1998.

Scully, M. E., Friedrichs, C., and Brubaker, J.: Control of estuarine stratification and mixing by wind-induced straining of the estuarine density field, Estuaries, 28, 321-326, 2005

Scully, M. E.: The importance of decadal-scale climate variability to wind-driven modulation of hypoxia in Chesapeake Bay, Nature Proceedings, hdl:10101/npre.2009.3308.1, 2009. 
Seitzinger, S.: Denitrification in freshwater and coastal marine systems: Ecological and geochemical significance, Limnol. Oceanogr., 33, 702-724, 1988.

Sharples, J., Simpson, J. H., and Brubaker, J. M.: Observations and modelling of periodic stratification in the Upper York River Estuary, Virginia, Estuar. Coast. Shelf S., 38, 301-312, 1994.

Shen, J., Wang, T., Herman, J., Mason, P., and Arnold, G.: Hypoxia in a coastal embayment of the Chesapeake Bay: A model diagnostic study of oxygen dynamics, Estuaries Coasts, 31, 652-663, 2008.

Slomp, C. P. and Van Cappellen, P.: The global marine phosphorus cycle: sensitivity to oceanic circulation, Biogeosciences, 4, 155171,2007 http://www.biogeosciences.net/4/155/2007/.

Smith, R. A., Alexander, R. B., and Wolman, M. G.: Water-quality trends in the nation's rivers, Science, 235, 1607-1615, 1987.

Soetaert, K., Middelburg, J. J., Heip, C., Meire, P., Van Damme, S., and Maris, T.: Long-term change in dissolved inorganic nutrients in the heterotrophic Scheldt estuary (Belgium, The Netherlands), Limnol. Oceanogr., 51, 409-423, 2006.

Soetaert, K. and Middelburg, J. J.: Modeling eutrophication and oligotrophication of shallow-water marine systems: The importance of sediments under stratified and well-mixed conditions, Hydrobiologia, 629, 239-254, 2009.

Stanley, D. W. and Nixon, S. W.: Stratification and bottom-water hypoxia in Pamlico River estuary, Estuaries, 15, 270-281, 1992.

Stigebrandt, A. and Gustafsson, B. G.: Improvement of Baltic Proper water quality using large-scale ecological engineering, Ambio, 36, 281-286, 2007.

Stock, C. and Dunne, J.: Controls on the ratio of mesozooplankton production to primary production in marine ecosystems, DeepSea Res. I, doi:10.1016/j.dsr.2009.10.006, in press, 2009.

Sylvan, J. B., Dortch, Q., Maier Brown, A. F. Morrison, W., and Ammerman, J. W.: Phosphorus limits phytoplankton growth on the Louisiana shelf during the period of hypoxia formation, Environ. Sci. Technol., 40, 7548-7553, 2006.

Taylor, A. H. and Stephens, J. A.: The North Atlantic Oscillation and the latitude of the Gulf Stream, Tellus, 50A, 134-142, 1998.

Testa, J. M., Kemp, W. M., Boynton, W. R., and Hagy, J. D.: Longterm changes in water quality and productivity in the Patuxent River estuary: 1985 to 2003, Estuaries Coasts, 31, 1021-1037, 2008.

Tiedje, J. M.: Ecology of denitrification and dissimilatory nitrate reduction to ammonium, in: Biology of Anaerobic Microorganisms, edited by: Zehnder, A. J. B., John Wiley, New York, 179244, 1987

Tinsley, D.: The Thames estuary: a history of the impact of humans on the environment and a description of the current approach to environmental management, in: A Rehabilitated Estuarine Ecosystem: The Environment and Ecology of the Thames Estuary, edited by: Attrill, M. J., Kluwer Academic Publishers, London, 2-25, 1998.

Turner, R. E., Schroeder, W. W., and Wiseman Jr., W. J.: The role of stratification in the deoxygenation of Mobile Bay and adjacent shelf bottom waters, Estuaries, 10, 13-19, 1987.

Turner, R. E., Rabalais, N. N., Swenson, E. M., Kasprzak, M., and Romaire, T.: Summer hypoxia in the northern Gulf of Mexico and its prediction from 1978 to 1995, Mar. Environ. Res., 59, 65-77, 2005.
Turner, R. E., Rabalais, N. N., Fry, B., Atilla, N., Milan, C. S., Lee, J. M., Normandeau, C., Oswald, T. A., Swenson, E. M., and Tomasko, D. A.: Paleo-indicators and water quality change in the Charlotte Harbor estuary (Florida), Limnol. Oceanogr., 51, 518-533, 2006a.

Turner, R. E., Rabalais, N. N., and Justić, D.: Predicting summer hypoxia in the northern Gulf of Mexico: riverine N, P and $\mathrm{Si}$ loading, Mar. Pollut. Bull., 52, 139-148, 2006b.

Turner, R. E., Rabalais, N. N., Alexander, R. B., McIssac, G., and Howarth, R. W.: Characterization of nutrient, organic carbon, and sediment loads and concentrations from the Mississippi River into the Northern Gulf of Mexico, Estuaries Coasts, 30, 773-790, 2007.

Turner, R. E., Rabalais, N. N., and Justić, D.: Gulf of Mexico hypoxia: Alternate states and a legacy, Environ. Sci. Technol., 42, 2323-2327, 2008.

Tyler, R. M., Brady, D. C., and Targett, T.: Temporal and spatial dynamics of diel-cycling hypoxia in estuarine tributaries, Estuaries Coasts, 32, 123-145, 2009.

Valiela, I.: Marine Ecological Processes, 2nd Edition, SpringerVerlag, New York, 1995

Van Beusekom, J. E. E., Loebl, M., and Martens, P.: Distant riverine nutrient supply and local temperature drive the long-term phytoplankton development in a temperate coastal basin, J. Sea Res., 61, 26-33, 2009.

Vaquer-Sunyer, R. and Duarte, C.: Thresholds of hypoxia for marine biodiversity, P. Natl. Acad. Sci. USA, 105, 15452-15457, 2008.

Welsh, B. L. and Eller, F. C.: Mechanisms controlling summertime oxygen depletion in western Long Island Sound, Estuaries, 14, 265-278, 1991.

Welsh, D. T.: It's a dirty job but someone has to do it: The role of marine benthic macrofauna in organic matter turnover and nutrient recycling to the water column, Chem. Ecol., 19, 321-342, 2003.

Wenner, E., Sanger, D., Arendt, M., Holland, A. F., and Chen, Y.: Variability in dissolved oxygen and other water-quality variables within the national estuarine research reserve system, J. Coastal Res., Special Issue 45, 17-38, 2004.

Westrich, J. T. and Berner, R. A.: The role of sedimentary organic matter in bacterial sulfate reduction: The G model tested, Limnol. Oceanogr., 29, 236-249, 1984.

Wiseman, W. J., Rabalais, N. N., Turner, R. E., Dinnel, S. P., and MacNaughton, A.: Seasonal and interannual variability within the Louisiana coastal current: stratification and hypoxia, J. Marine Syst., 12, 237-248, 1997.

Wilson, R. E., Swanson, R. L., and Crowley, H. A.: Perspectives on long-term variations in hypoxic conditions in western Long Island Sound, J. Geophys. Res., 113, C12011, doi:10.1029/2007JC004693, 2008.

Wiseman, W. J., Rabalais, N. N., Turner, R. E., and Justić, D.: Hypoxia and the physics of the Louisiana coastal current, in: Dying and Dead Seas: NATO Advanced Research Workshop, Liège, Belgium, NATO ASI Series, edited by: Nihoul, J. C. J., Zavialov, P. O., and Micklin, P. P., Kluwer Academic Publishers, The Netherlands, 359-372, 2004.

Wulff, F., Savchuk, O. P., Sokolov, A., Humborg, C., and Mörth, C.-M.: Management options and effects on a marine ecosystem: Assessing the future of the Baltic, Ambio, 36, 243-249, 2007. 
Yin, K., Lin, Z., and Ke, Z.: Temporal and spatial distribution of dissolved oxygen in the Pearl River Estuary and adjacent coastal waters, Cont. Shelf Res., 24, 1935-1948, 2004.

Zhang, J., Gilbert, D., Gooday, A., Levin, L., Naqvi, W., Middelburg, J., Scranton, M., Ekau, W., Pena, A., Dewitte, B., Oguz, T., Monteiro, P. M. S., Urban, E., Rabalais, N., Ittekkot, V., Kemp, W. M., Ulloa, O., Elmgren, R., Escobar-Briones, E., and Van der Plas, A.: Natural and human-induced hypoxia and consequences for coastal areas: synthesis and future development, Biogeosciences Discuss., 6, 11035-11087, 2009,

http://www.biogeosciences-discuss.net/6/11035/2009/.
Zillén, L., Conley, D. J., Andrén, T., Andrén, E., and Gjörck, S.: Past occurrences of hypoxia in the Baltic Sea and the role of climate variability, environmental change and human impact, Earth-Sci. Rev., 91, 77-92, 2008. 